Life Sciences Contribution Royal Ontario Museum

92

Communal Hierarchy and Significance of

Environmental Parameters for Brachiopods:

the New Zealand Permian Model

J. Bruce Waterhouse

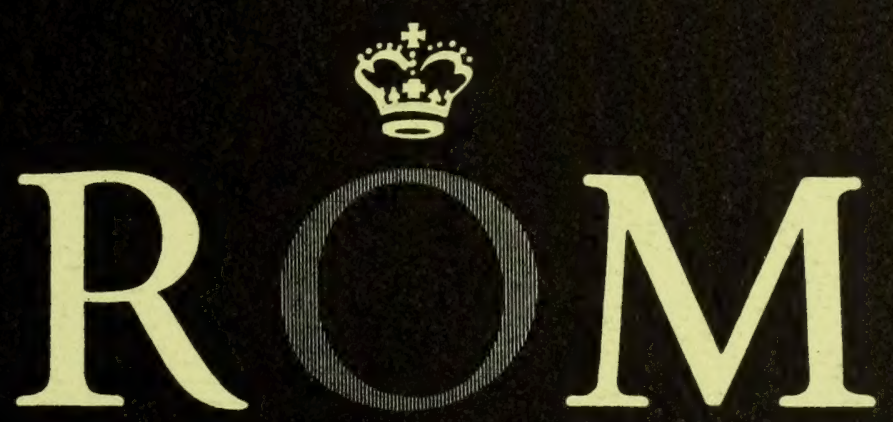


Digitized by the Internet Archive in 2011 with funding from University of Toronto 
LIFE SCIENCES CONTRIBUTIONS

ROYAL ONTARIO MUSEUM

NUMBER 92

J. BRUCE WATERHOUSE

Communal Hierarchy

and Significance of

Environmental Parameters

for Brachiopods: the

New Zealand Permian Model

Publication date: 27 November 1973

ISBN 0-88854-138-4

Suggested citation: Life Sci. Contr., R. Ont. Mus. 


\section{ROYAL ONTARIO MUSEUM PUBLICATIONS IN LIFE SCIENCES}

The Royal Ontario Museum publishes three series in the Life Sciences:

LIFE SCIENCES CONTRIBUTIONS, a numbered series of original scientific publications, including monographic works.

LIFE SCIENCES OCCASIONAL PAPERS, a numbered series of original scientific publications, primarily short and usually of taxonomic significance.

LIFE SCIENCES MISCELLANEOUS PUBLICATIONS, an unnumbered series of publications of varied subject matter and format.

All manuscripts considered for publication are subject to the scrutiny and editorial policies of the Life Sciences Editorial Board, and to review by persons outside the Museum staff who are authorities in the particular field involved.

\section{LIFE SCIENCES EDITORIAL BOARD}

R. L. PETERSON, Chairman

J. R. TAMSITT, Editor

D. BARR, Associate Editor

E. J. CROSSMAN, Associate Editor

J. Bruce Waterhouse is Associate Professor of Geology at the University of Toronto, and a Research Associate in the Department of Invertebrate Palaeontology, Royal Ontario Museum.

PRICE：\$2.00

(1)The Royal Ontario Museum, 1973

100 Queen's Park, Toronto, Canada

PRINTED AT THE UNIVERSITY OF TORONTO PRESS 


\section{Contents}

Introduction, 1

Lithic and Environmental Setting, 2

Autecology - Mode of Attachment, 4

Synecology, 7

Summary of Brachiopod Communities, 11

Parameters Affecting Brachiopods, 15

Summary, 18

Acknowledgments, 19

Literature Cited, 19

Tables, 23

Figures, 33 



\title{
Communal Hierarchy and Significance of Environmental Parameters for Brachiopods: the New Zealand Permian Model
}

\begin{abstract}
Within the fossil marine environment, temperature appears to have been of prime significance in influencing the composition of faunas. Lithofacies, salinity, and biotic competition are more important at the systematic level of specifically-based communities and subcommunities. The interplay between these and other factors as displayed in the development of brachiopod faunas is appropriately expressed by an hierarchy of partly overlapping, partly exclusive communities. These communities may be grouped in recurrent generic communities, which in turn may be organised into supercommunities. Further complexity results because the response of Permian brachiopods to substrate and other environmental parameters varied considerably within brachiopod orders, affecting some at the familial level, and others at generic, specific, or infraspecific levels.
\end{abstract}

\section{Introduction}

More than 150 brachiopod species belonging to 50 genera are known from the New Zealand Permian. They occur in 15 zones (two correlative) ranging in age from early to late Permian (Tables 1,2), from 100 formally designated localities, some 20 of which are extensive and cover 10 to 50 feet of vertical thickness through fossiliferous beds and layers (Waterhouse, in press). About 200 other marine species are known, half of which have been described in publications, as summarized by Waterhouse (1970). Such control over the systematics, correlation, and lithofacies allows a preliminary study of the paleoecology. Paleoecology of Permian biota has been largely neglected apart from significant studies by Newell et al (1953), Ross (1967), Yochelson (1968), Waterhouse and Piyasin (1970), a few insignificant autecological studies, and individual counts of various phyla provided by Soviet paleontologists (e.g. Ruzencev and Sarytcheva, 1965). These published studies were based on carbonates and clastics of a shelf environment, apart from the extensive but brief survey of Fusulinacea by Ross (1967). The present study is based on a much more complicated environment, over a long period, at the leading edge of a plate margin. As with other leading plate margins of upper Paleozoic age, the New Zealand one has suffered orogenesis that has restricted and distorted outcrops and accordingly limited the amount of data available. But such environments should not be ignored, because they were as widespread in the past as in the present day. Moreover, 
the New Zealand leading edge is exceptionally well preserved among Paleozoic examples. As shown by Waterhouse and Norris (1972), it buckled inwards during orogeny instead of pushing outwards as thrusts and nappes, as is usually the case, so that the sequences are still relatively intact.

Because of the volume of documentation involved, few paleoecologic studies published to date provide more than conclusions, so that a work is rarely testable. For the purposes of this paper, some data are tabulated, and the remainder presented elsewhere (Waterhouse, in press). Attention is given individual counts from each locality to assess the degree to which specimens were found in living position or in a reworked condition, to detailed lithofacies, and to environment. Conclusions established in the work in press are summarized and used herein.

Materials: Most of the material examined is stored at the New Zealand Geological Survey, Lower Hutt, New Zealand. Some material is stored at the Department of Geology, Victoria University, Wellington, and some at the Department of Geology, University of Otago, Dunedin. Fossil localities are registered serially by number with the prefix GS, and are described in Waterhouse (in press).

\section{Lithic and Environmental Setting}

Throughout much of its geologic history New Zealand has been situated at the leading edge of a tectonic plate at the interface between Gondwana and the Pacific (Fig. 1). The overall environment in which Permian brachiopods lived (Figs. 2-4) was that of an ensimatic geosyncline bordered by a volcanic arc and craton that probably formed part of the Gondwana supercontinent (Waterhouse and Norris, 1972). The craton, composed largely of Lower Paleozoic rock, was briefly covered by a mid-Permian, shallow, marine incursion that deposited quartzitic sands, pebble beds, and carbonaceous silts containing brachiopods of the Notospirifer spinosa Zone.

To seaward lay the volcanic arc, consisting chiefly of ankaramitic and basaltic sheet lava, which was occasionally flooded by marine incursions depositing sediment containing brachiopods (Fig. 4). An enormous, clastic wedge of volcanic detritus containing some lava flows and igneous intrusions accumulated to seaward in foreset beds with an apparent thickness of 16,000 $\mathrm{m}$ during the early Permian period (Waituna Facies, Fig. 5). Brachiopods in the zones of Notostrophia sp. A, Notostrophia homeri Waterhouse (1973), Martinia adentata Waterhouse (1964b) and Echinalosia prideri (Coleman, 1957) are scattered through the succession (Tables 1,2). Greywacke and spilite accumulated to seaward in deeper water, one facies with ultramafic flows and sills (Waitai Facies), the other without ultramafics (Pukeawa Facies, Figs. 5, 7). These facies were too deep or in some other unexplainable way unsuited for colonization by brachiopods, although the epifaunal bivalve Atomodesma attached by byssus was common (Waterhouse, 1964a) in the Waitai facies.

By mid-Permian times the clastic wedge stabilised as a shelf and received thin clastic and carbonate sediments, richly fossiliferous in places, that were 
separated by numerous unconformities (Figs. 3, 4, 6, 8). Eight zones and subzones of brachiopods were recognised by Waterhouse (in press) Terrakea concavum Waterhouse (1964b), Echinalosia maxwelli (Waterhouse, 1964b), Aperispirifer sp. B of Waterhouse (1968), Echinalosia ovalis (Maxwell, 1954), Terrakea brachythaerum (Morris, 1845), Plekonella multicostata Waterhouse (1964b), A perispirifer nelsonensis (Waterhouse 1964b) and Wairakiella rostrata Waterhouse (1967). The zones and subzones occurred in a variety of sediments, ranging from transgressive conglomerates, sandstones rich in bivalves, brachiopod shell banks (biostromes), coral bioherms, to calcilutites. Volcanicity ceased at the top of the Terrakea brachythaerum Zone and was followed by an interval of carbonate deposition, which blanketed the entire New Zealand Geosyncline but not the craton and was widely colonised by scattered patches of brachiopods that comprised the zones of Plekonella multicostata Waterhouse (1964b) and Martiniopsis woodi Waterhouse (1964b).

Brachiopods are common over the mid-geosynclinal Clutha Ridge (Figs. 2, 6, 8), which began to emerge in Kalabaghian times about $150 \mathrm{~km}$ seaward of the volcanic arc (Waterhouse and Norris, 1972). Over the ridge the carbonates were locally replaced by silts and muds, which supported fenestellid or stenoporid bryozoa. The overlying, more quartz-rich siltstone and sandstone (Waterhouse, 1964a) deposited in shallow water contained a few Capillonia and Attenuatella, assigned to no particular zone. These beds were covered in turn by coarse sandstone and carbonate with brachiopods of the zone of Spinomartinia spinosa Waterhouse (1968), found on the Clutha Ridge, inner shelf calcarenites, and outer shelf calcilutites and siltstones. The seafloor between the outer shelf and the Clutha Ridge then collapsed to form the beginning of the Mokoreka Trough, which was filled by deep water turbidites and laminites of the Greville Formation with rare Atomodesma, ammonoids, and worm tubes, the depth being too great for brachiopods. Carbonate lenses at the top of the succession were colonised by faunas of the zone of Aperispirifer nelsonensis Waterhouse (1964b) found also in transgressive, rubbly, stenoporid limestones and conglomerates of the shelf sequence. Seaward to the Clutha Ridge thin sediment accumulated in the Aotearoa Trough. The youngest Permian brachiopods are found in the zone of Wairakiella rostrata Waterhouse (1967) in transgressive conglomerates and sandstones at the top of the shelf sequence.

Generally, the stratigraphic record is a complex one of shifting axes of deposition and elevation, in which slope and the source and volume of sediment changed from time to time. As a result a wide range of marine facies are represented, some in narrow belts more or less parallel to the shore, others broad. New Zealand rarely attained the simplicity exhibited in the epeiric seas discussed by Anderson (1971), usually having a much greater range of biotopes, many of which were restricted in space and time because of interference from climate, volcanicity, or tectonism. Fluctuating changes in depth probably helped shift brachiopod habitats towards and away from the shore line (Table 3 ) and gave rise to a variety of different facies in any vertical sequence (Fig. 3; Waterhouse, 1964a; Waterhouse and Norris, 1972). 


\section{Autecology — Mode of Attachment}

One method of analysing brachiopod autecology is by the mode of attachment to the substrate. Waterhouse and Piyasin (1970) recognised several modes of attachment in Permian faunas that may be illustrated by New Zealand examples:

a. Umbonal scar: Orthotetida (e.g. Grumantia, Notostrophia), cemented by umbonal cicatrix.

b. Umbonal scar and spines: Strophalosiacea (e.g. Echinalosia, Wyndhamia, Taeniothaerus, Aulosteges), cemented by umbonal cicatrix and spines.

c. Spines: Productacea (e.g. Terrakea, Cancrinella, Lethamia) or Chonetidina (Neochonetes), cemented by spines.

d. Pedicle: 1 ) passing through foramen; Rhynchonellida (Plekonella), some Spiriferida (Cleiothyridina), and Terebratulida (Fletcherithyris). Shells elevated by the pedicle above substrate, oval in shape with narrow hinge. 2) passing through delthyrium; Spiriferida (Neospirifer, Martinia, Tomiopsis). Many shells also stabilised by possessing a long hinge resting on or in the seafloor sediment.

e. Proppers: (e.g., Attenuatella), unattached, resting against other shells or sediment.

The summary of modes of attachment in various lithofacies set out in Figs. 9 and 10 shows that some brachiopods were apparently affected by sediment, others not, within the limits of available data. From the analyses detailed by Waterhouse (in press) most brachiopods appear to have responded to substrate, but not at any fixed taxonomic level. Species of some families however were strongly affected by substrate. Although most common genera appear to have been virtually independent of lithofacies (Table 4), many were controlled at a specific level by substrate, whereas others were unaffected even at intraspecific levels, as shown by the distribution of species and lithologies (see Table 5).

\section{UMBONAL ATTACHMENT SCAR}

Species of the genera Grumantia and Notostrophia of the Family Schuchertellidae, Order Orthotetida, are generally restricted to rock with pebbles or breccia, as though attached to rocks close to shore, so that their distribution was influenced by substrate at least in New Zealand.

\section{UMBONAL SCAR AND SPINES}

Echinalosia and Wyndhamia (superfamily Strophalosiacea, order Productida) were able to modify their environment by forming banks of living shells in silty or calcareous lithofacies on which successive generations could flourish. In other conditions they did not establish such successful colonies but inhabited many sea bottoms, except habitats dominated by Bryozoa and corals (Table 4). Thus substrate did not usually affect the presence or absence of species of the genera Echinalosia and Wyndhamia but did influence numbers of individuals and also elicited individual responses in musculature and spinosity, as shown by Waterhouse (1964b). 
Members of the Aulostegidae (superfamily Strophalosiacea) were less tolerant, as interpreted from the meagre samples available. Species of Aulosteges, Taeniothaerus, and the morphologically, somewhat similar genus Waagenoconcha (Productacea) were limited to grits and coarse sands. The assertion by Grant (1966) that Waagenoconcha with its array of fine hairlike spines was specially adapted to dwell in soft ooze is not supported by field study. Waagenoconcha and allies generally occur in sandstone of tightly-packed, coarse, bioclastic carbonate and seldom in mudstone or siltstone, at least in New Zealand, Australia, and the Arctic. Perhaps the allegedly soft, calcareous ooze quoted by Grant (1966) as a substrate for some Waagenoconcha had become firm - certainly no proof has been provided that it was soft.

\section{SPINES}

The Chonetidina were a suborder of minimal diversity and wide tolerance. Neochonetes beatusi and Capillonia brevisulcus inhabited a wide range of facies, those of Neochonetes preferring siltstone. They appear to have been influenced by substrate chiefly at an infraspecific level. By contrast, species of the spinose superfamily Productacea were highly diverse, and species within many genera were adapted to a restricted environment. Species of Terrakea with numerous ear spines have been found in coarse sediment, whereas species with few ear spines appear to have been limited to siltstones, carbonates, or biostromes (Waterhouse, 1971a). Each species has been found in a different kind of sediment. Species of Cancrinella were also restricted to a distinctive lithology, and both species of Lethamia were found only in siltstone. Species of the genus Horridonia occurred in fenestellid siltstone and sandy siltstone, and a species of the genus Sowerbina was found in calcilutite.

\section{DELTHYRIAL PEDICLE}

Members of the order Spiriferida, attached by means of a delthyrial pedicle, were numerous in most fossiliferous facies. Many rested on their long hinges, and because their centre of gravity was low, probably coped with various hydrographical conditions. Judging from the distributions set out in Table 5, they probably lived mostly in gravel, grit, sand and shelly mud, and were not taxonomically diverse, though still numerous, in calcareous mud, silt, and stenoporid grit. Limited response to substrate is discernible at the generic and specific level. One species of Spiriferella was abundant in calcareous silts, another in calcareous breccia. Species of Aperispirifer were generally found throughout the range of lithofacies available, except for sand; they comprised a significant component of the fauna but were rarely the most numerous brachiopod except in facies unfavourable for most brachiopods, such as coral bioherms or stenoporid thickets. Species of Tomiopsis were also prominent in many communities throughout a wide range of facies, from breccia to soft ooze but were rare in near-shore sandy environments inhabited by infaunal bivalves. Species of the closely related Notospirifer were found less often than those of Tomiopsis in breccia or conglomerate and were more numerous in sandstone. Martinia has been found chiefly in 
coarse sandstone and breccia rather than in fine sandstone, and the related genus Spinomartinia occurred in a wide variety of lithologies including calcarenite, calcilutite, mixed conglomerate mudstone, and fine sandstone. Species of the genus Pustuloplica were common only in breccia or calcarenite. Spiriferid species tolerated a wide range of lithofacies, and morphological response to substrate seems to have been limited to nuances of microornament, musculature controlling valve opening and closing, and alation, all of which helped govern stability. This response is shown by the range of facies presented in Table 5, and by systematic description, as in Waterhouse (1964b).

\section{UMBONAL PEDICLE}

Shells with a pedicle through an umbonal foramen were suspended above the sea floor and thus were potentially unaffected by lithofacies, provided that the holdfast could remain attached to either the sea floor or perhaps to seaweed. Advantages of feeding without hindrance from sediment were such that brachiopods of several different orders adopted this mode of attachment. Yet, although less intimately connected with lithofacies, a number of these brachiopod species were restricted to few lithofacies (Table 5).

Among the Rhynchonellida, "nests" or clusters of Plekonella species were found chiefly in sandstone, but the genus was widespread in various lithologies. Wairakiella rostrata Waterhouse (1967) was found in breccia and sandstone. A species of Psilocamara was dominant in volcanic breccia. Individuals of Stenoscisma were numerous only in clean siltstone with sandy layers and were rare in nearby contemporaneous facies dominated by fenestellids or in calcilutites. Specimens of the athyrid Cleiothvridina were numerous only in siltstone. Species of the terebratulid Fletcherithyris were found chiefly in sandstone and in biostromes, except for the more widely distributed $F$. galbina. Other Terebratulida were generally limited to fine sandstone or siltstone.

\section{PROPPERS}

Shells of Attenuatella were propped in the sediment without any pedicle (Waterhouse, 1964b) and have been collected from siltstone and from the extensive locality over Clutha Ridge where muddy layers are mixed with sandy and conglomeratic lenses. Shells ranged from conglomerate to calcareous mudstone and were absent only from stenoporid grit. There were no shelly biostromes during the stratigraphic range of species of this genus in New Zealand.

\section{Summary of Modes of Attachment in Different Sediments}

With emphasis on sediments, Figs. 9 and 10 show that calcareous muds, though represented by many localities, had meagre faunas of low diversity and were dominated by spiny Productida and Spiriferida. Stenoporid grit and coral bioherms were dominated by spiriferids, with only a few other brachiopods present. Strophalosiid biostromes possessed larger faunas but lacked proppers or shells attached solely by an umbonal scar. Remaining lithologies had a more balanced representation apart from those attached by 
umbonal scar, with Spiriferida predominant. Grit and biostromes supported more species of Strophalosiacea than Productacea, and silt, mud, and sand supported more species of Productacea than Strophalosiacea.

Changing predominance of different modes of attachment through time is shown in Figs. 11 and 12. The Spiriferida which were attached by a delthyrial pedicle occupied a persistently pre-eminent position, judging from the numbers of species present and at intervals on the basis of individual specimens. Populations of spiny Productida increased and decreased. To some extent they were limited in faunal diversity because of competition with the Strophalosiacea.

\section{Synecology}

\section{COMMUNITIES AND SUBCOMMUNITIES}

A biotic community is broadly defined as "any assemblage of populations in a prescribed area or physical habitat" (Odum and Odum, 1959). According to some paleontologists (Bretsky, 1969, 1970; Ziegler, Cocks, and Bambach, 1968; Ziegler, Cocks, and McKerrow, 1968; Anderson, 1971) fossil marine communities are recurrent associations of numerically dominant species. Recognition that communities recur throughout the fossil record provides a valuable means to test environmental restraints for the community but is not intrinsic to the community concept. Therefore, Raup and Stanley (1971, p. 229) proposed that such communities be called "recurrent communities."

In neontology, "dominant" species are regarded as those that control the community to a greater or lesser degree, as distinct from "primary" species, which, though numerous individually, do not play a role in influencing the rest of the community. The difference may be difficult to assess for fossil shell-fish. Corals, Bryozoa, Orthotetida, and Strophalosiacea likely played a dominant role in some communities in that they altered the nature of the substrate for the remaining shell-fish to a considerable extent. But in many other environments a particular brachiopod species would be more appropriately considered a "primary," rather than a "dominant."

In neontology the concept of numerical preponderance is often unduly restrictive; tropical plant communities, for instance, have so many species in the role of dominants that a taxonomic and dominant basis is regarded as unworkable (Richards, 1952). But numbers in New Zealand brachiopod faunas, as in other fossil faunas, may be assessed objectively, and the concept is retained herein as a prerequisite for interpreting fossil communities. Numerical preponderance within fossil faunas frequently oscillates between two or three primary species in restricted areas, and these nuances may be enumerated by subdividing the community into subcommunities (see Odum and Odum, 1959, p. 254).

Various distributional patterns can be established for brachiopods. Species of the rhynchonellid genus Plekonella often formed clusters or "nests" that may be distinguished as Plekonella subcommunities. Individuals of the genera Grumantia, Echinalosia and Attenuatella were able to spread out from small clusters interspersed among other species to carpet extensive patches of sea floor as primary species. Some abundant spiriferids, e.g. Tomiopsis, 
had a pattern of wide individual dispersal. These different patterns of colonization resulted in a plexus of interrelated associations that may be treated as communities or, preferably, subcommunities. Some freedom is needed in recognising either several communities or one community with subcommunities in the mosaic of the contemporaneous faunas.

\section{GENERIC COMMUNITIES, SUPERCOMMUNITIES AND BIOMES}

Even within a conservative framework some 50 communities and subcommunities may be recognised among New Zealand Permian brachiopods, reflecting the fact that brachiopod species were short lived, and that they occupied diverse, constantly changing habitats. Such a large number of communities encourages recognition of major groupings that may be more easily handled. Brachiopod genera were more persistent than species, and about 20 key genera characterized New Zealand Permian communities. I call these communities "generic communities" defined by recurrent associations of numerically preponderant genera. Generic communities recurred episodically within successions as persistent as a series or period, and are also found in different geographic areas as distinct species of the same genus. In turn, two to four generic communities are frequently bonded to the exclusion of other linked generic communities. These are here called supercommunities, defined as assemblages of linked generic communities. Supercommunities are somewhat similar in concept to those that have been called "associations" or "major communities" in the plant kingdom (Clark, 1954, p. 443). The term "supercommunity" is preferable, to imply a hierarchy including the "subcommunity."

On a global scale and for as long as a period, supercommunities have been associated in a few major groupings, which appear to be analogous to present day biomes, such as tropical forest, deciduous forests, tundra, and grasslands. They are here called fossil biomes. The fossil biome is defined as "associations of supercommunities with significant and sometimes numerically dominant genera, linked to environment." Like biomes of today, they were a "complex of communities maintained under the climatic conditions of the region" (Clarke, 1963, p. 448). Only a few fossil biomes are recognisable in any one period and, being widespread, they have considerable promise for climatic and paleogeographic interpretations. Permian fossil biomes are in part reflected by seven major groupingss in world distributions of Permian brachiopod families recognised by Waterhouse and BonhamCarter (1972) from Q-mode cluster analysis, but biomes should be defined by genera rather than families. There is some difficulty in referring to the Permian biomes by name because parallels in the marine Permian to terms for modern biomes do not exist. When world coverage is achieved, it would be appropriate to use some code or numerical system. In the meantime, two biomes recognised here are informally named after a widespread and characteristic genus. When wide coverage is achieved, it may be found that the choice of name was not the most appropriate. Sylvester-Bradley (1971, p. 13) also used the word biome in a somewhat similar sense, with emphasis on local magnafacies. The two concepts merge, but I classify coral reefs, for example, as communities (or at best a supercommunity) in a tropical biome, 
whereas Sylvester-Bradley (1971, p. 13) referred coral reefs to a distinct biome.

Almost alone among paleontologists, Bretsky $(1969,1970)$ also indicated communal hierarchy by recognising so-called "multi-species populations," perhaps equivalent to subcommunities, and "communities," which in turn were distributed in "associations." Anderson (1971) used "association" in place of Bretsky's "population." Bretsky (1969, p. 53) appeared to have envisaged the three divisions as components of a simple, linear model.

\section{Aperispirifer Fossil Biome}

The distribution and interrelationships of subcommunities, communities and generic communities are summarized in Figs. 13-15. Communities are assessed on the basis of systematic descriptions (e.g. Waterhouse, 1964b, 1967), stratigraphy and lithology (e.g. Waterhouse, 1964a; Waterhouse and Norris, 1972), and individual counts from every fossil locality in New Zealand (Waterhouse, in press). Detailed interpretation of habitat, species by species, is also provided in Waterhouse (in press). The most complex and widespread fossil biome in the New Zealand Permian is informally termed the Aperispirifer biome, characterised by Aperispirifer and such selective brachiopod genera as Neochonetes, Echinalosia, Wyndhamia, Terrakea, Plekonella, Tomiopsis, Notospirifer, and Fletcherithyris. Other biota included slightly less exclusive bivalves such as Myonia and Megadesmus, gastropods such as Walnichollsia, Mourlonopsis, and Spirovallum, and the coral Euryphyllum. This biome was prevalent in New Zealand for most of the Permian Period and was also widespread at intervals in parts of Gondwana and also northeast Siberia, Arctic Canada, and Alaska. Several generic communities may be recognised in New Zealand and are centred around Notostrophia, Neochonetes, Echinalosia, Wyndhamia, Plekonella, Psilocamara, Spiriferella, Tomiopsis, and Notospirifer. There was, moreover, a natural clustering between Echinalosia, Notostrophia, and Neochonetes on one hand (Echinalosia Supercommunity) and Wyndhamia and Spiriferella on the other (Wyndhamia Supercommunity). A few widespread genera, Plekonella, A perispirifer, Notospirifer, and Fletcherithyris were not so restrictive, occurring in various communal combinations. Within the supercommunities are various communities, delimited by the numerical preponderance of certain species and interlinked by shared species and genera. Considerable intergradation occurred throughout restricted or expanded ecotones in some instances, whereas other ecotones were abrupt and sharply restricted. There were in addition subcommunities dominated by nests of Plekonella or widely dispersed, local populations of Tomiopsis and Notospirifer.

Within the Echinalosia supercommunity, Echinalosia was one of the major, recurrent generic communities. Neochonetes was a primary genus of some communities. Species of this genus were moderately dispersed, capable of blanketing an area, but without such effective control of the substrate as that exerted by species of Echinalosia. Notostrophia dominated several communities, potentially with the same control as that exerted by Echinalosia. Species of Notostrophia and of the allied genus Grumantia are generally 
found with Echinalosia. Specimens of Terrakea were widespread in New Zealand Permian communities especially with Echinalosia or Wyndhamia. The spiny-eared lineage (Waterhouse, 1971) generally occurred with Echinalosia, and the smooth-eared lineage was found with Wyndhamia, though there are sufficient exceptions to rule out any firm association. Many assemblages in eastern Australia and a few in Arctic Canada were dominated by Terrakea.

In the Wyndhamia Supercommunity, Wyndhamia was similar to Echinalosia in habitat and dominated communities in New Zealand, Australia, and north-east Siberia (Waterhouse, 1969a). Wyndhamia occurred with Echinalosia in rare instances, as in the Tomiopsis spinosa Zone (Fig. 16) in one New Zealand Permian community that lacks Aperispirifer. Faunas from this zone in New Zealand have unique attributes (Waterhouse and Vella, 1965) and conceivably belonged to another fossil biome typical of colder waters and found widely in east Australia and parts of Gondwana (Waterhouse and Norris, 1972). But further analysis is necessary to establish its distinctiveness.

Species of Spiriferella dominated communities in the Wyndhamia supercommunity. This genus characterised various Permian faunas of the Arctic, Himalayas and Timor. Notospirifer was a primary genus of one community and abundant in others. Tomiopsis occasionally was of primary significance, especially in subcommunities, and was found in a coral bioherm with Aperispirifer.

\section{Attenuatella Fossil Biome}

A second major grouping of communities and supercommunities (Fig. 14), centred around the genus Attenuatella, was developed in several stages and zones in New Zealand. From a preliminary assessment of the literature, allied supercommunities with modified generic content are found in Australia and the Arctic (Bamber and Waterhouse, 1971). Some numerically preponderant genera were restricted to one or other biome, and others were shared by the two biomes, suggesting a gradational contact between the two, as ecotonal and as natural as contacts between biomes of the present day. Gradation is well shown by Martinia, which was a primary species of communities in the Attenuatella biome, and has been found with Wyndhamia in the Aperispirifer biome. The Notostrophia generic community was also probably close to the interface between the two biomes because it included Psilocamara, found rarely in the Attenuatella biome. A major cluster of communities grouped around the genus Echinalosia and the more exclusive genera, Aulosteges, Taeniothaerus, and Waagenoconcha. Another supercommunity centred around the genus Capillonia, which has been found widely with Attenuatella in various communities. Species of Capillonia were found to the exclusion of Neochonetes (likely to have been a direct competitor), Echinalosia, Wyndhamia, Notostrophia, and Grumantia. Other communities were dominated by Notospirifer, the exclusive genus Stenoscisma, or by less selective species of Tomiopsis and Notospirifer, genera which exhibited no marked preference for one or another biome.

Other New Zealand Permian communities had Neospirifer and Mar- 
tiniopsis as primary or important species. Neospirifer occurred to the exclusion of the related genus Aperispirifer. In many Permian communities Tomiopsis and Martiniopsis were mutually exclusive (Waterhouse, 1971b) as in some New Zealand communities. But at times, during the Aktastinian and Makarewan stages, the region of New Zealand clearly occupied the interface between the two competing genera, with both present in Psilocamara saginatum and Wairakiella rostrata communities (Table 5). Functionally, and at any suprageneric taxonomic level, the Neospirifer-Martiniopsis community closely resembled an Aperispirifer-Tomiopsis community, in both coral or bryozoan bioherms, and illustrates how almost identical niches were occupied by similar genera belonging to different biomes.

\section{Wairakiella rostrata Zone}

A third somewhat anomalous major faunal grouping (Fig. 15) characterised by Rhynchonellida, Terebratulida, and Spiriferida was limited to the latest Permian and is known only from New Zealand. Unlike other Permian faunas, Orthotetida, Productida and other brachiopods that disappeared at the end of the Late Paleozoic era are lacking, and the fauna is thus to some extent Triassic in appearance. The species are members of Permian genera, and none are Triassic (Waterhouse, 1967). They are identical to those found as elements of the Attenuatella biome and probably represent an impoverished relict of that fossil biome.

\section{Summary of Brachiopod Communities (Fig. 11)}

\section{Notostrophia zealandicus Zone}

The Psilocamara saginatum-Plekonella campbelli community found in volcanic breccia with dense muddy or silty matrix, had Psilocamara as a primary species and also contained Plekonella, numerous spiriferids attached by delthyrium, and fewer Productida. Bands of Notostrophia represented a second community in much the same lithofacies. In both communities proppers and Terebratulida were rare; Bryozoa were numerous, and gastropods common, with a few epifaunal bivalves (nestling, free-swinging and free swimming), and rare solitary Rugosa (Table 6). Communities developed near a rocky volcanic shore in a highly disturbed environment.

\section{Notostrophia homeri Zone (Fig. 11)}

Lithologies and accompanying biota were almost identical with the underlying $N$. zealandicus Zone, except for the presence of slightly more sand. The predominant community was preserved as repeated bands of scattered or heaped Notostrophia homeri, which lived attached by an umbonal scar, and were accompanied by numerous Bryozoa, and scattered Tomiopsis, other Spiriferida, and Terrakea. Echinalosia, specifically adapted for survival in active waters (Waterhouse, 1964b), formed pockets with Bryozoa and Spiriferida, which represented another community or subcommunity. Faunas are much less diverse than those of the underlying Notostrophia zealandicus Zone, although there is little difference in lithology, and no evidence for change of depth or salinity. 
Martinia adentata Zone

Martinia was the primary species in subrounded conglomerates which were deposited rapidly somewhat farther from shore than the underlying breccias of the Notostrophia zones. The strophalosiid Wyndhamia was abundant in identical lithologies. Pleurotomariid gastropods, numerous in some bands, were prime species in fine sandstone with the brachiopod Psilocamara.

\section{Echinalosia prideri Zone}

Faunas of this zone were found scattered sparsely through grits and sandstone deposited in slightly deeper water than the conglomerates of the underlying Martinia zone. Vestiges of several communities were preserved, to some extent characteristic of different lithologies. Echinalosia prideri has been found in sandstone with spiriferids. Taeniothaerus and Aulosteges in coarser sandstone and grit probably represent vestiges of distinct communities. Fine sandstone and siltstone have yielded numerous specimens of Attenuatella and a few Martinia but no spiny shells. Fenestellidae, Stenoporidae, solitary Rugosa, epifaunal Bivalvia attached by byssus, Gastropoda, and other biota were infrequent or rare.

\section{Terrakea concavum Zone}

Four communities are known from this zone. One, affected by transportation, has numerous Spiriferella supplanta found in siltstone with comminuted fenestellid bryozoa. Other prominent brachiopods included Aperispirifer wairakiensis and Plekonella acuta. Scyphozoa, numerous gastropods, and a few bivalves, both epifaunal (Pectinacea) and infaunal (Anomalodesmata), were less conspicuous. A second community, the primary species being Neochonetes beatusi, has been found in shelly grit and siltstone at the top of the zone with Terrakea concavum and infaunal, siphonate suspension feeders (Anomalodesmata). Echinalosia maxwelli formed a subzone and a distinct third community in several biostromes with Terrakea concavum, Plekonella acuta, Aperispirifer wairakiensis, and other spiriferids such as Tomiopsis and Notospirifer. A pleurotomariid gastropod Peruvispira was common throughout, and another, Mourlonopsis, is preserved in layers. Epifaunal nestling bivalves (Stutchburia and Atomodesma), free-swinging Streblochondria, and the swimming Etheripecten were also present with rare Bryozoa and Scaphopoda. The biostromes developed in shallow water mudstones with numerous silt-sized prisms of Atomodesma and are separated by sandstones dominated by infaunal Bivalvia.

\section{Aperispirifer B Zone}

Two spiriferid genera characterized by a long hinge and a delthyrial pedicle were found in a community of solitary rugose and tabulate corals. No other kind of brachiopod was present.

\section{Notospirifer spinosa Zone}

Notospirifer spinosa and, in some bands, Tomiopsis ingelarensis were primary species in the pebbly arkosic quartzites and fine or coarse quartzitic sandstones of this zone and were associated with numerous Terrakea brachythaerum, some strophalosiids, and various fenestellids. Bivalvia were 
few, either as burrowers (Anomalodesmata) or epifauna (Etheripecten). In addition, there were gastropods and crinoids but no corals. Carbon, probably plant-derived, is abundant in the sediment. The zone is correlative with the Aperispirifer B Zone, and was formed in shallow water near shore during cold conditions (Waterhouse and Vella, 1965).

\section{Echinalosia ovalis Zone}

A variety of lithofacies and faunas occurred in this zone, with evidence for at least six communal entities. The Neochonetes beatusi community in the upper part of the Terrakea concavum Zone has been found at intervals in siltstone and fine sandstone associated with species of Tomiopsis, Terrakea and a few Anomalodesmata. In the underlying zone Neochonetes was found in coarser lithology with different species. From the extensive localities grouped as GS3616 (see Waterhouse, 1964b), Tomiopsis mantuanesis occurred in layers with some Echinalosia and Terrakea. Communities with Grumantia pelicanensis, Echinalosia and Aperispirifer resembled the Notostrophia communities of the early Permian. Terrakea elongatum was locally predominant in sandy and especially silty bands, which were deposited at slightly greater depths than various sandstones which were dominated by Terrakea brachythaerum (Waterhouse, 1964b). T. elongatum was accompanied by Plekonella and Fletcherithyris. Plekonella southlandensis was found in nests in siltstone and sandstone. Throughout the siltstones, bivalves were diverse, and included siphonate suspension feeders (Anomalodesmata), detritus feeders (Palaeotaxodonta - see Waterhouse, 1964c, 1969c), and free-swinging or swimming suspension feeders (Pterioida) with a few nestling forms. Scattered Gastropoda, Rugosa, and Fenestellidae were also present.

Well-sorted calcareous siltstones supported a different community, characterised by the productid Lethamia and numerous Spiriferida, attached by umbonal pedicle (Cleiothyridina) or delthyrial pedicle (Aperispirifer, Tomiopsis). Fenestellid Bryozoa, Pectinacea, and Pleurotomariacean gastropods were also present.

\section{Terrakea brachythaerum Zone}

Terrakea brachythaerum was the primary brachiopod species in a variety of lithologies ranging from very coarse to fine sandstone, and also shelly mudstone. Fletcherithyris was second in number, with Tomiopsis costata prominent in coarse sandstone, and Notospirifer macropustulosus was widespread.

Infaunal bivalves (Palaeotaxodonta and Anomalodesmata) were numerically preponderant in plant-bearing sandstone formed in shallow depths probably near shore, and were accompanied by epifaunal Bivalvia and Gastropoda, with rare Scaphopoda, Scyphozoa, and Stenoporidae.

\section{Martiniopsis woodi Zone}

Martiniopsis woodi was the only brachiopod found in near-shore calcilutites and in compound rugose coral bioherms far from the volcanic arc. This species also occurred with stenoporid bryozoa in volcanic grits on the Clutha 
Ridge, where another spiriferid, Neospirifer, was the primary species with the occasional Waagenoconcha.

\section{Plekonella multicostata Zone}

In this zone Tomiopsis parallela was a primary species in fenestellid silts of the Clutha Ridge that were deposited in shallow waters far from the volcanic arc, with Plekonella multicostata also conspicuous. In the same area sandy' siltstones with few fenestellids contained Stenoscisma papilio as a primary species with the chonetid Capillonia and Attenuatella. In finer, less sandy siltstones and some fenestellid siltstones the latter two genera were more numerous. Shells attached by umbonal scar and cicatrix were not found in either facies. Terrakea, Echinalosia and Plekonella multicostata occurred in nearshore calcilutites. The epifaunal, nestling bivalve Atomodesma woodi Waterhouse (1963) was locally numerous, and prisms from this species made up much of the extensive carbonates of this horizon. Gastropods were diverse over the Clutha Ridge, but other biota (solitary Rugosa, Scyphozoa, Nautiloidea, and Echinodermata) were rare. Spiriferella cf. rajah has been found in calcareous breccia in beds slightly younger than the Plekonella multicostata Zone.

\section{Capillonia-Attenuatella Beds}

These two genera, persisting from the underlying into overlying zones, have been found in nearshore calcilutites. Capillonia has also been found in coarse volcanic grits. Extensive siltstone and fine sandstone of the same age supported innumerable specimens of the nestling bivalve Atomodesma trechmanni (Marwick, 1935) — see Waterhouse (1964a).

\section{Spinomartinia spinosa Zone}

Capillonia brevisulcus was numerous in conglomerates, sandstones, siltstones, and penecontemporaneous reworked beds on Clutha Ridge, formed far from the volcanic arc in high energy conditions with intervals of quiescence during which muds were deposited. The Spiriferida Attenuatella and Spinomartinia were less common, and were accompanied by diverse and moderately numerous gastropods and the nestling bivalve Atomodesma trabeculum Waterhouse (1963) which was much more widespread throughout correlative coarse sandstones of the upper Annear and Little Ben formations. The same community of Capillonia, Attenuatella and Spinomartinia has been found in siltstone, sandstone and calcilutites of the outer shelf. In a calcareous subarenite nearshore, Attenuatella was the primary species with Spinomartinia and numerous gastropods but without Capillonia.

\section{Aperispirifer nelsonensis Zone}

This zone, represented chiefly as calcilutite lenses with layers of volcanic grit and sandstone, was dominated by strophalosiid biostromes of Wyndhamia planata, with scattered Plekonella, Aperispirifer, and Tomiopsis. The community resembled the Echinalosia maxwelli community of mid-Permian siltstones, though found in different lithofacies and tectofacies. Tomiopsis was predominant in pure calcareous muds (more than $90 \%$ calcium car- 
bonate), and Aperispirifer has been found in sandy beds, and in shallow water conglomerates and carbonates. Plekonella occurred in clusters. In all facies gastropods and epifaunal bivalves occupied minor niches, apart from pockets of the pleurotomariid Peruvispira. Members of other phyla were rare.

\section{Wairakiella rostrata Zone}

Wairakiella rostrata, attached by an umbonal pedicle, was widespread in breccia, conglomerate, and sandstone, with Aperispirifer prominent in one band of conglomerate, and Plekonella iniquitas common. Martiniopsis plata was found in highly calcareous breccias of a facies very different from lithofacies with $M$. woodi. Fenestellids, stenoporids, and crinoid fragments were common, and molluscs were rare.

\section{Parameters Affecting Brachiopods}

\section{LITHOFACIES AND TECTOFACIES}

According to Anderson (1971, p. 287), "It is generally agreed that communities and community patterns are dependent on sedimentary environment." Copper (1966) showed that atrypid biotopes were lithologically controlled in zones arranged parallel to shore, and Ager (1971) argued for "bottom-control," with most significance assigned to "the energy level of water as reflected in sediment" (1971, p. 101). From studies of roadside outcrops in the Appalachian Mountains, Bretsky (1970) showed that three Upper Ordovician communities were controlled by lithofacies. Purdy (1964) demonstrated how various authorities have regarded the substrate as either highly significant, or much less significant than salinity or hydrography in control of populations. Yet, an all-or-nothing approach is probably inappropriate for Permian brachiopods. One conclusion of the present study is that brachiopods responded differently to substrate, at family levels in some, intraspecifically in others. Possibly significant is that Copper (1966) and Ager (1971), who emphasized lithofacies, discussed shells that adhered by means of foramenal pedicle, a type of shell shown here to have been more sensitive to the sea bottom than the Strophalosiacea attached by spines and umbonal scar or Spiriferida attached by delthyrial pedicle. Even so, the Permian Rhynchonellida seem to have been less influenced by bottom facies than the Jurassic Rhynchonellida studied by Ager (1971), suggesting increased sensitivity and specialisation by Mesozoic times.

\section{TEMPERATURE}

Temperature played a significant role in the distribution of brachiopods and composition in Ordovician (Williams, 1969; Spjeldnaes, 1961) and Permian communities (Stehli, 1957; Waterhouse, 1969b). Both Stehli and Waterhouse assessed the effect of temperature on generic and family diversity, which increased from poles to equator. Using Q-mode cluster analyses for virtually all known familial occurrences of Permian brachiopods, Waterhouse and Bonham-Carter (1972) delineated seven faunal associations that varied in diversity over the globe, in their opinion according to temperature. The world pattern of distribution of brachiopods at a familial level sug- 
gested independence from minute salinity differences, depth of water, provincialism, or lithofacies, other than such temperature-dependent substrates as tillite, dolomite, coral reefs, and sediments formed under highly saline conditions. But Waterhouse and Bonham-Carter (1972) emphasized that assessments could be further refined and that high salinities affected the distribution of brachiopod families.

Unlike some other parameters considered to be significant in controlling brachiopod distribution, temperature can be estimated by independent methods. Oxygen-isotope ratios in shells of Australian Permian brachiopods assessed by Compston (1960) and Dorman and Gill (1959) show that correlatives of the Aperispirifer biome in New Zealand were cold-water and that correlates of the New Zealand Attenuatella fossil biome were warmwater (Waterhouse and Bonham-Carter, 1972). Judging from the distribution of glacial tillites, Gondwana glaciation, followed by initial recovery times, occurred when Aperispirifer communities flourished in New Zealand. The Attenuatella faunas flourished in New Zealand during warm episodes.

\section{INFLUENCE OF WATER DEPTH}

Sedimentary wedges, especially if ensimatic or at the leading edge of an actively moving tectonic plate, have steep profiles habitable within narrow limits. In New Zealand the habitable zone shifted episodically and occupied different facies as maturation of the geosyncline progressed (Table 3 ). Within the narrow habitable zone, sandstones rich in plant material and infaunal bivalvia probably represented shallow-water, inshore deposits and supported Terrakea brachythaerum communities, whereas more rocky, shallow waters developed communities of Notostrophia or Grumantia. In either community depth of water need not have been a more significant environmental influence than substrate, temperature or hydrography. Throughout the early Permian, progressive change in faunas also occurred with increased depth (judging from fineness of lithology), but communal development may have been intimately related to substrate and temperature. Three mid-Permian brachiopod zones ( $M$. woodi, $P$. multicostata, $S$. spinosa) are exposed for a distance of $150 \mathrm{~km}$ from shore and do not exhibit any well-defined series of communities that changed progressively farther from shore. In some extensive localities, such as those of the Notostrophia zones, the recurrent communities dominated by various species may reflect slight changes in depth.

Data for New Zealand are insufficient to test whether Permian brachiopods were influenced by water depth to the same extent as was proposed by Ziegler, Cocks and Bambach (1968) and Ziegler, Cocks and McKerrow (1968) for mid-Paleozoic brachiopod faunas in Wales. These authors recognized five recurrent communities over a broad shelf in the Upper Llandoverian beds. The five communities were stated to be independent of substrate (Ziegler, Cocks, and Bambach, 1968, p. 25; Ziegler, Cocks, and McKerrow, 1968, p. 776), though Ager (1971, p. 99) expressed doubt, and no detailed quantitative analyses have yet been provided except single instances of the five "type communities." According to Ziegler, Cocks and Bambach (1968) the prime influence was depth of water, differences of 10 to $20 \mathrm{ft}$ being crucial. Similar communities were traced in North America by 
Ziegler and Boucot (1971), with reference to genera rather than to species. The influence of depth was possibly strong in the Appalachian communities recognised by Bretsky (1970) and the atrypid distribution discussed by Copper (1966) in Europe.

It is of course virtually impossible to make any direct measurements of water depth from the fossil record, and difficult enough to use the lithologic record. Stevens (1969, p. 121) cautioned workers about "the aura of speculation" that surrounds various estimates of depth. Theoretical difficulties that arise from the assertions by Ziegler, Cocks and Bambach (1968) may not be relevant to the Welsh examples, but do hinder any application to Permian examples. For instance, statements that the Welsh communities were independent of lithofacies, but at the same time indicated mysterious submarine unconformities imply that neither lithologies nor unconformities were used to interpret depth, leaving "distance from shore" as the chief independent criterion for "depth." Distance from shore is normally a haphazard and unreliable criterion of depth, and virtually impossible to translate into quantitative measurements. A special argument used for the Welsh examples, based on the change in depth caused by emplacement of lavas, is almost meaningless until it is demonstrated that brachiopods were in no way influenced by substrate, and that no significant time lapse occurred before and after the outpouring of lava. It is noteworthy that intercorrelation between communities is based on subspecies of different brachiopod genera. In theory this is a tenuous thread for correlation, normally justifiable on a pragmatic basis only after correlation already has been established by other means. Communal changes were apparently instantaneous, although evidence against time-transgressive changes in sea-level has not yet been provided. Rapid changes in depth over extensive areas, especially miogeoclines, normally indicate glacio-eustatic changes of sea-level (Daly, 1936; Burke and Waterhouse, 1973), and if glacio-eustatic changes were operating, then temperature must have played a major role in changing depth and position of the shore-line, as well as probably having a more direct effect. Indeed, Parker (1963, p. 39) concluded that apparently depth-controlled faunas off the shore of California today were affected primarily by temperature rather than water pressure. Parker's data imply that faunas would move to and from shore with changes in temperature. Yet Ziegler, Cocks and Bambach (1968) and Ziegler, Cocks and McKerrow (1968) did not discuss the effect of temperature, even though it may have been a significant parameter. If the Silurian examples are correctly interpreted by Ziegler and co-workers, brachiopods apparently were more complex in their response to environmental changes by Permian times, becoming more sensitive to both lithofacies and temperature and seemingly more tolerant of depth than Silurian brachiopods. Certainly in the broad Permian platform of the Yukon territory, Canada (Bamber and Waterhouse, 1971), as in the limited example of New Zealand, changes in Permian brachiopods faunas with depth were limited.

\section{SALINITY}

Salinity as with depth is difficult to gauge from the fossil or lithologic record, except in extreme examples. Obviously fossils indicate a marine or nonmarine environment, and extremely saline conditions are betrayed by both 
lithofacies and biofacies. Permian brachiopods from highly saline waters include peculiar genera and are often limited in diversity (Waterhouse and Bonham-Carter, 1972). But beyond these limits it would seem reasonable to ascribe variation in faunal communities to salinity only when all other causes are ruled out. Claims that salinity was a major factor or even "the main factor in the marine environment" (Hewer, 1971, p. 24; Hallam, 1969) find minimal support from Permian or other periods in so far as the actual salt content has rarely been given, and other factors have seldom been ruled out either by thorough analysis of a region, or by a study of world distributions - which provides the most satisfactory basis for detecting the influence of temperature. The difficulty of conducting such research may explain why workers on local problems have failed to realise the significance of temperature and have allotted undue importance to minor environmental parameters.

\section{Summary}

Habitats available to Permian brachiopods living over the sedimentary prism at the leading edge of a tectonic plate were extremely diverse, often compressed, and short-lived because of tectonic activity. In addition, severe climatic changes affected faunas and were apparently of major importance in changing supercommunities and biomes. Analyses of New Zealand data suggest that brachiopods responded variously to lithofacies. Orthotetida, Terebratulida, and some Spiriferida appear to have been sensitive to substrate, the former adapted to live in coarse lithologies, the latter two in sands and silts. In contrast, the Strophalosiacea and Productacea lived in a variety of habitats, often inversely proportional to each other in numbers of individuals, species, and genera, with an apparent paucity of Strophalosiidae in bryozoan colonies. Both are scarce or absent only from coral reefs in New Zealand. The Strophalosiidae were slightly less adapted specifically and generically to substrate than the Productacea but were more capable of shaping their own environment by building biostromes, especially on areas of slow or fine sedimentation. Among the Productacea, some species and genera appear to have adapted to particular lithofacies. On the other hand, species of Chonetidina were remarkably widespread in a variety of facies.

Transverse or oval Spiriferida that adhered by a delthyrial pedicle were also independent of facies. Species of some genera showed some preferences, but most were widely distributed. Many species responded only intraspecifically to a variety of substrates. Spiriferids that were unattached were also independent of substrate.

From synecological analyses, the New Zealand Permian brachiopods were organized into a complex hierarchy of subcommunities and communities, grouped further into recurrent generic communities. About 20 important genera were involved, bonded into a few exclusive "supercommunities," which in turn formed two major fossil biomes throughout the New Zealand Permian period.

According to a model proposed herein, prime control on the brachiopod segment of the faunas within the habitable range of Permian seas was exerted by temperature, many brachiopod genera and even families having 
such restricted temperature thresholds that they migrated in response to the fluctuating temperatures of the Permian period. Temperature thus controlled the composition of biomes and influenced faunal associations to the subcommunal level. The actual presence of genera and species was affected by lithofacies, presence and competition of other biota, and possibly depth and salinity of water. These factors also influenced size of populations and the morphology of individuals and species to varying degree in different taxa.

\section{Acknowledgments}

Mr T. J. Barrett, Department of Geology, University of Toronto, kindly read the manuscript. Text figures were drafted with the help of Messrs F. Jurgenheit and B. O'Donovan, Department of Geology, University of Toronto, and Mr R. Balgavis, Ontario Department of Mines, Toronto.

\section{Literature Cited}

AGER, D. V.

1971 Space and time in brachiopod history. In Middlemiss, F. A., P. F. Rawson, G. Newall, eds. Faunal provinces in space and time. Liverpool, Seel House Press, pp. 95-110.

ANDERSON, E. J.

1971 Environmental models for Paleozoic communities. Lethaia, vol. 4, no. 3 , pp. 287-302.

BAMBER, E. W. AND J. B. WATERHOUSE

1971 Carboniferous and Permian stratigraphy and palaeontology, Northern Yukon Territory, Canada. Bull. Can. Petrol. Geol., vol. 19, no. 1, pp. 29-250.

BRETSKY, P. W.

1969 Evolution of Paleozoic benthic marine invertebrate communities. Palaeogeography, Palaeoclimatology, Palaeoecology, vol. 6, pp. 4559.

1970 Upper Ordovician ecology of the Central Appalachians. Bull. Peabody Mus. Nat. Hist., no. 34, pp. 1-150.

BURKE, K. AND J. B. WATERHOUSE

1973 Saharan Glaciation dated in North America. Nature, vol. 241, no. 5387, pp. 267-268.

CLARKE, G. L.

1954 Elements of ecology. New York, J. Wiley. 534 pp.

COLEMAN, P. J.

1957 Permian Productacea of Western Australia. Bull. Bur. Miner. Resour. Geol. Geophys. Aust., no. 40, pp. 1-188.

COMPSTON, W.

1960 The carbon isotopic compositions of certain marine invertebrates and coals from the Australian Permian. Geochim. Cosmochim. Acta, vol. 18 , pp. $1-22$. 
COPPER, P.

1966 Ecologic distribution of Devonian atrypid brachiopods. Palaeogeography, Palaeoclimatology, Palaeoecology, vol. 2, pp. 245-266.

DALY, R. A.

1936 Origin of submarine canyons. Am. J. Sci., ser. 5, vol. 31, no. 186, pp. 401-420.

DORMAN, F. H. AND E. D. GILL

1959 Oxygen isotope paleotemperature measurements on Australian fossils. Proc. R. Soc. Vict., n.s., no. 71, pp. 73-98.

GRANT, R. E.

1966 A Permian productoid brachiopod: life history. Science, vol. 152, no. 3722 , pp. $660-662$.

HALLAM, A.

1969 Faunal realms and facies in the Jurassic. Palaeontology, vol. 12, pt. 1, pp. 1-18.

HEWER, H. R.

1971 Modern zoological regions. In Middlemiss, F. A., P. F. Rawson, G. Newall, eds. Faunal provinces in space and time. Liverpool, Seel House Press, pp. 19-30.

MARWICK, J.

1935 Some new genera of the Myalinidae and Pteriidae of New Zealand.

Trans. R. Soc. N.Z., vol. 65, pp. 295-303.

MAXWELL, W. G. H.

1954 Strophalosia in the Permian of Queensland. J. Paleont., vol. 28, no. 5 , pp. 533-559.

MORRIS, J.

1845 [Descriptions of fossils] In Strzelecki, P. E. Physical description of New South Wales and Van Diemen's Land. London, Longman, Brown, Green and Longmans, pp. 270-289.

ODUM, E. P. AND H. T. ODUM

1959 Fundamentals of ecology. 2nd ed. Philadelphia, W. B. Saunders. $546 \mathrm{pp}$.

NEWELL, N. D., J. K. RIGBY, A. G. FISCHER, A. J. WHITEMAN, J. E. HICKOX AND J. S. BRADLEY

1953 The Permian reef complex of the Guadalupe Mountains region, Texas and New Mexico; a study in paleoecology. San Francisco, W. H. Freeman. 236 pp.

PARKER, R. H.

1963 Zoogeography and ecology of some macroinvertebrates, particularly mollusks, in the Gulf of California, and continental slope off Mexico.

Vidensk. Meddr. Dansk Naturh. Foren., vol. 126, pp. 1-178.

PURDY, E. G.

1964 Sediments as substrates. In Imbrie, J., N. D. Newell, eds. Approaches to paleoecology. New York, Wiley, pp. 238-271.

RAUP, D. M. AND S. M. STANLEY

1971 Principles of paleontology. San Francisco, W. H. Freeman. 388 pp. 
RICHARDS, P. W.

1952 The tropical rain-forest; an ecological study. Cambridge, University Press. $450 \mathrm{pp}$.

Ross, C. A.

1967 Development of fusulinid (Foraminiferida) faunal realms. J. Paleont., vol. 41, no. 6, pp. 1341-1354.

RUZENCEV, V. E. AND T. G. SARYTCHEVA

1965 The development and succession of marine organisms at the Paleozoic-Mesozoic boundary. Trudy Paleont. Inst. Mosc., vol. 108, 431 pp.

SPJELDNAES, N.

1961 Ordovician climatic zones. Norsk Geol. Tidsskr., vol. 41, pp. 45-77.

STEHLI, F. G.

1957 Possible permian climatic zonation and its implications. Am. J. Sci., vol. 255 , no. 9 , pp. 607-618.

STEVENS, C. H.

1969 Water depth control of fusulinid distribution. Lethaia, vol. 2, no. 2, pp. 121-132.

SYLVESTER-BRADLEY, P. C.

1971 Dynamic factors in animal palaeogeography. In Middlemiss, F. A., P. F. Rawson, G. Newall, eds. Faunal provinces in space and time. Liverpool, Seel House Press, pp. 1-18.

WATERHOUSE, J. B.

1963 New Zealand species of the Permian bivalve Atomodesma Beyrich. Palaeontology, vol. 6, pt. 4, pp. 699-717.

1964a Permian stratigraphy and faunas of New Zealand. Bull. Geol. Surv. N.Z., n.s., no. 72, pp. 1-101.

1964b Permian brachiopods of New Zealand. Palaeont. Bull., Wellington, no. 35, pp. 1-287.

1964c Palaeotaxodont bivalves from the Permian of New Zealand. Palaeontology, vol. 7, pt. 4, pp. 630-655.

1967 Upper Permian (Tatarian) brachiopods from New Zealand. N.Z. J. Geol. Geophys., vol. 10, no. 1, pp. 74-118.

1968 The classification and descriptions of Permian spiriferida (Brachiopoda) from New Zealand. Palaeontographica, vol. 129A, pp. 1-94.

1969a Permian Strophalosiidae (Brachiopoda) from the Canadian Arctic Archipelago. J. Paleont., vol. 43, no. 1, pp. 28-40.

$1969 \mathrm{~b}$ The Palaeoclimatic significance of Permian Productacea from Queensland. In Campbell, K. S. W., ed. Stratigraphy and palaeontology; essays in honour of Dorothy Hill. Canberra, Australian National University Press, pp. 226-235.

1969c The Permian bivalve genera Myonia, Megadesmus, Vacunella and their allies, and their occurrences in New Zealand. Palaeont. Bull., Wellington, no. 41, pp. 1-141.

1970 The world significance of New Zealand Permian stages. Trans. R. Soc. N.Z., Vol. 7, no. 7, pp. 97-109.

1971a The Permian brachiopod genus Terrakea Booker, 1930. In Dutro, J. T. ed. Paleozoic perspectives: A paleontological tribute to G. Arthur Cooper. Smithson. Contr. Paleobiology, no. 3, pp. 347-361. 
1971b The brachiopod genus Tomiopsis Benedictova from the Permian of Canada. J. Paleont., vol. 45, no. 1, pp. 68-80.

1973 New Permian brachiopod genera from New Zealand. J. R. Soc. N.Z., vol. 4, Part 1, pp. 35-42.

In press Brachiopod systematics, zonation and paleoecology for the New Zealand Permian. Palaeont. Bull., Wellington.

WATERHOUSE, J. B. AND G. BONHAM-CARTER

1972 Permian paleolatitudes judged from brachiopod diversitites. In Mamet, M. and A. Hallam, eds. Sect. 7. Paleontology. Proc. 24th Int. Geol. Congr., Canada, 1972. Gardenvale, Quebec, Harpell's Press Co-op, pp. 350-361.

WATERHOUSE, J. B. AND G. NORRIS

1972 A Paleobotanical solution to a granite conundrum: Hawks Crag Breccia of New Zealand and the tectonic evolution of the south-west Pacific. Geoscience and Man, vol. 4, pp. 1-15.

WATERHOUSE, J. B. AND S. PIYASIN

1970 Mid-Permian brachiopods from Khao Phrik, Thailand. Palaeontographica, abt. A, band 135, lieferung 3-6, pp. 83-197.

WATERHOUSE, J. B. AND P. VELLA

1965 A Permian fauna from north-west Nelson, New Zealand. Trans. R. Soc. N.Z., vol. 3, no. 5, pp. 57-84.

WILLIAMS, A.

1969 Ordovician faunal provinces with reference to brachiopod distribution. In Wood, A., ed. The Precambrian and Lower Paleozoic rocks of Wales. Cardiff, University of Wales Press, pp. 117-154.

YOCHELSON, E. L.

1968 Biostratigraphy of the Phosphoria, Park City and Shedhorn formations. Prof. Pap. U.S. Geol. Surv., no. 313D, pp. 571-660.

ZIEGLER, A. M. AND A. J. BOUCOT

1971 North American Silurian animal communities. In Berry, W. B. N., A. J. Boucot, eds. Correlation of the North American Silurian rocks. Spec. Pap. Geol. Soc. Am., no. 102, pp. 95106.

ZIEGLER, A. M., L. R. M. COCKS AND R. K. BAMBACH

1968 The composition and structure of Lower Silurian marine communities. Lethaia, vol. 1, no. 1, pp. 1-27.

ZIEGLER, A. M., L. R. M. COCKS AND W. S. MCKERROW

1968 Llandovery transgression of the Welsh borderland. Palaeontology, vol. 11 , pt. 5, pp. 736-782. 
TABLES 
TABLE 1 Summary of Brachiopod Zones in New Zealand Permian (Waterhouse, in press)

\begin{tabular}{|c|c|c|c|}
\hline $\begin{array}{l}\text { World } \\
\text { Stage }\end{array}$ & $\begin{array}{l}\text { Zone } \\
\text { number }\end{array}$ & Name of Zone & Other Guide Species \\
\hline $\begin{array}{l}\text { ?Dienerian- } \\
\text { Ogbinan }\end{array}$ & 15 & $\begin{array}{l}\text { Wairakiella rostrata } \\
\text { assemblage and range } \\
\text { zone }\end{array}$ & $\begin{array}{l}\text { Plekonella iniquitas, } \\
\text { Martiniopsis patella, } \\
\text { Aygdalocosta rara }\end{array}$ \\
\hline Vedian & 14 & $\begin{array}{l}\text { Aperispirifer nelsonensis } \\
\text { assemblage and range } \\
\text { zone }\end{array}$ & $\begin{array}{l}\text { Wyndhamia planata, } \\
\text { Tomiopsis furca }\end{array}$ \\
\hline ?Chhidruan & 13 & $\begin{array}{l}\text { Spinomartinia spinosa } \\
\text { range zone }\end{array}$ & $\begin{array}{l}\text { Acme for Capillonia } \\
\text { brevisulcus }\end{array}$ \\
\hline ?Chhidruan & - & $\begin{array}{l}\text { Capillonia and Attenua- } \\
\text { tella beds }\end{array}$ & \\
\hline ?Kalabaghian & 12 & $\begin{array}{l}\text { Plekonella multicostata } \\
\text { assemblage zone }\end{array}$ & $\begin{array}{l}\text { Marinurnula rugulata. } \\
\text { Lacks key species of } M \text {. } \\
\text { woodi and } S \text {. spinosa zones, } \\
\text { otherwise with many similar } \\
\text { species }\end{array}$ \\
\hline ?Kalabaghian & 11 & $\begin{array}{l}\text { Martiniopsis woodi } \\
\text { range zone }\end{array}$ & $\begin{array}{l}\text { Acme for Neospirifer arthur- } \\
\text { tonensis }\end{array}$ \\
\hline $\begin{array}{l}\text { Kazanian } \\
\text { upper }\end{array}$ & 10 & $\begin{array}{l}\text { Terrakea brachythaerum } \\
\text { acme zone }\end{array}$ & $\begin{array}{l}\text { Also assemblage zone with } \\
\text { species of Wyndhamia, Spiri- } \\
\text { ferellina, and Tomiopsis }\end{array}$ \\
\hline $\begin{array}{l}\text { Kazanian } \\
\text { lower }\end{array}$ & 9 & $\begin{array}{l}\text { Echinalosia ovalis } \\
\text { assemblage zone }\end{array}$ & $\begin{array}{l}\text { Grumantia pelicanensis, } \\
\text { Plekonella southlandensis } \\
\text { Tomiopsis mantuanensis }\end{array}$ \\
\hline Ufimian & $8(=7)$ & $\begin{array}{l}\text { Notospirifer spinosa } \\
\text { range zone }\end{array}$ & $\begin{array}{l}\text { Otherwise with assemblage } \\
\text { similar to T. brachythaerum } \\
\text { and } E \text {. ovalis zones }\end{array}$ \\
\hline Ufimian & 7 & $\begin{array}{l}\text { Aperispirifer } \mathbf{B} \\
\text { range zone }\end{array}$ & \\
\hline Elkin & 6 & $\begin{array}{l}\text { Echinalosia maxwelli } \\
\text { subzone - range zone }\end{array}$ & Within Terrakea concavum zone \\
\hline Nevolin & 5 & $\begin{array}{l}\text { Terrakea concavum } \\
\text { range and assemblage } \\
\text { zone }\end{array}$ & $\begin{array}{l}\text { Notospirifer microstriatus } \\
\text { overlap with Plekonella } \\
\text { acuta }\end{array}$ \\
\hline Krasnoufimian & 4 & $\begin{array}{l}\text { Echinalosia prideri } \\
\text { assemblage zone }\end{array}$ & Taeniothaerus \\
\hline Sarginian & 3 & $\begin{array}{l}\text { Martinia adentata } \\
\text { assemblage and range } \\
\text { zone }\end{array}$ & Wyndhamia jukesi \\
\hline Aktastinian & $\begin{array}{l}2 \\
1\end{array}$ & $\begin{array}{l}\text { Notostrophia homeri } \\
\text { range zone } \\
\text { Notostrophia zealandicus } \\
\text { range zone }\end{array}$ & $\begin{array}{l}\text { Assemblage similar to that of } \\
N . \text { zealandicus } \\
\text { Echinalosia, Terrakea pollex }\end{array}$ \\
\hline
\end{tabular}


TABle 2 Brachiopod zones and stratigraphic history for the Permian segment of the New Zealand Geosyncline

\begin{tabular}{|c|c|c|}
\hline Stage or substage & Brachiopod zone & New Zealand Geosyncline \\
\hline Makarewan & Wairakiella rostrata & ? Subturbidites, breccias on shelf \\
\hline Ogbinan & - & Subturbidites, unconformity on shelf \\
\hline $\begin{array}{l}\text { Waiitian } \\
\text { (=upper Vedian) }\end{array}$ & $\begin{array}{l}\text { Aperispirifer } \\
\text { nelsonensis }\end{array}$ & Widespread carbonate lenses \\
\hline Vedian & - & $\begin{array}{l}\text { ? Red shales followed by unconformity } \\
\text { and tilloid and slump conglomerate. } \\
\text { Unconformity, conglomerate on shelf }\end{array}$ \\
\hline $\begin{array}{l}\text { Baisalian } \\
\text { "Kathwai", }\end{array}$ & - & $\begin{array}{l}\text { ? Collapse of Greville trough, } \\
\text { rapidly filled by turbidites-laminites. } \\
\text { Unconformity on shelf }\end{array}$ \\
\hline Chhidruan & Spinomartinia spinosa & $\begin{array}{l}\text { Siltstone, followed by diastem } \\
\text { then quartz rich sandstone }\end{array}$ \\
\hline Kalabaghian & $\begin{array}{l}\text { Plekonella multicostata } \\
\text { Martiniopsis woodi }\end{array}$ & Limestone deposition widespread \\
\hline Kazanian & $\begin{array}{l}\text { Terrakea brachythaerum } \\
\text { Echinalosia ovalis }\end{array}$ & $\begin{array}{l}\text { Continued volcanicity, with } \\
\text { emplacement of Dun Mountain } \\
\text { ultramafics, multiple conglomerates }\end{array}$ \\
\hline Ufimian & $\begin{array}{l}\text { Notospirifer spinosa }= \\
\text { Aperispirifer sp 'B' }\end{array}$ & $\begin{array}{l}\text { Fine clastic sediment in shelf and } \\
\text { geosyncline, volcanicity continued }\end{array}$ \\
\hline \multicolumn{3}{|l|}{ Kungurian } \\
\hline $\begin{array}{l}\text { Elkin } \\
\text { Nevolin } \\
\text { Filippovian }\end{array}$ & $\begin{array}{l}\text { Echinalosia maxwelli } \\
\text { Terrakea concavum } \\
-\end{array}$ & $\begin{array}{l}\text { Basic and ultrabasic volcanicity } \\
\text { resumed on volcanic arc and geosyncline. } \\
\text { Breccias over clastic wedge, and } \\
\text { conglomerate at base of Arthurton } \\
\text { Group }\end{array}$ \\
\hline Krasnoufimian & Echinalosia prideri & Cessation of volcanic activity, \\
\hline Sarginian & Martinia adentata & $\begin{array}{l}\text { marine submergence of volcanic arc, } \\
\text { rapid build up of clastic wedge in } \\
\text { Takitimu Group }\end{array}$ \\
\hline Aktastinian & $\begin{array}{l}\text { Notostrophia homeri } \\
\text { N. zealandicus }\end{array}$ & $\begin{array}{l}\text { Widespread volcanicity in volcanic } \\
\text { arc and geosyncline, and greywacke } \\
\text { sedimentation }\end{array}$ \\
\hline
\end{tabular}




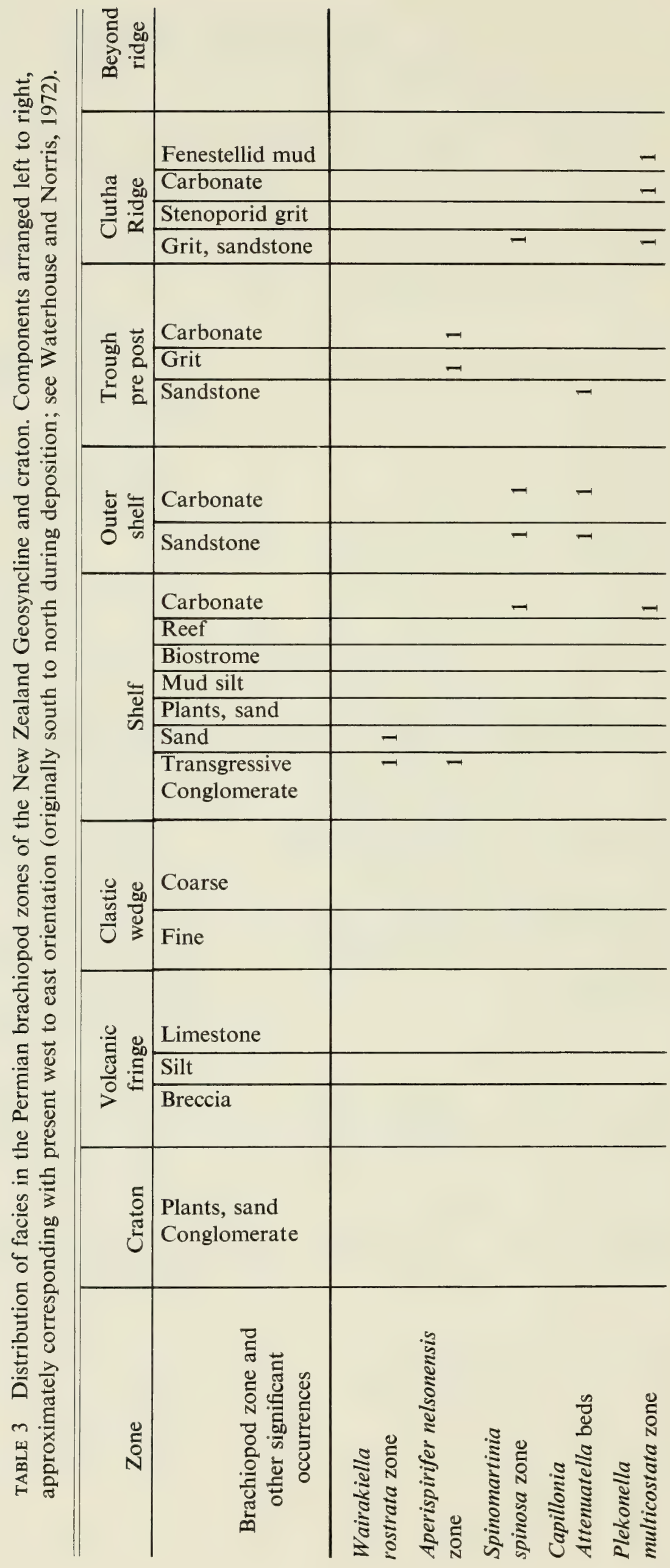




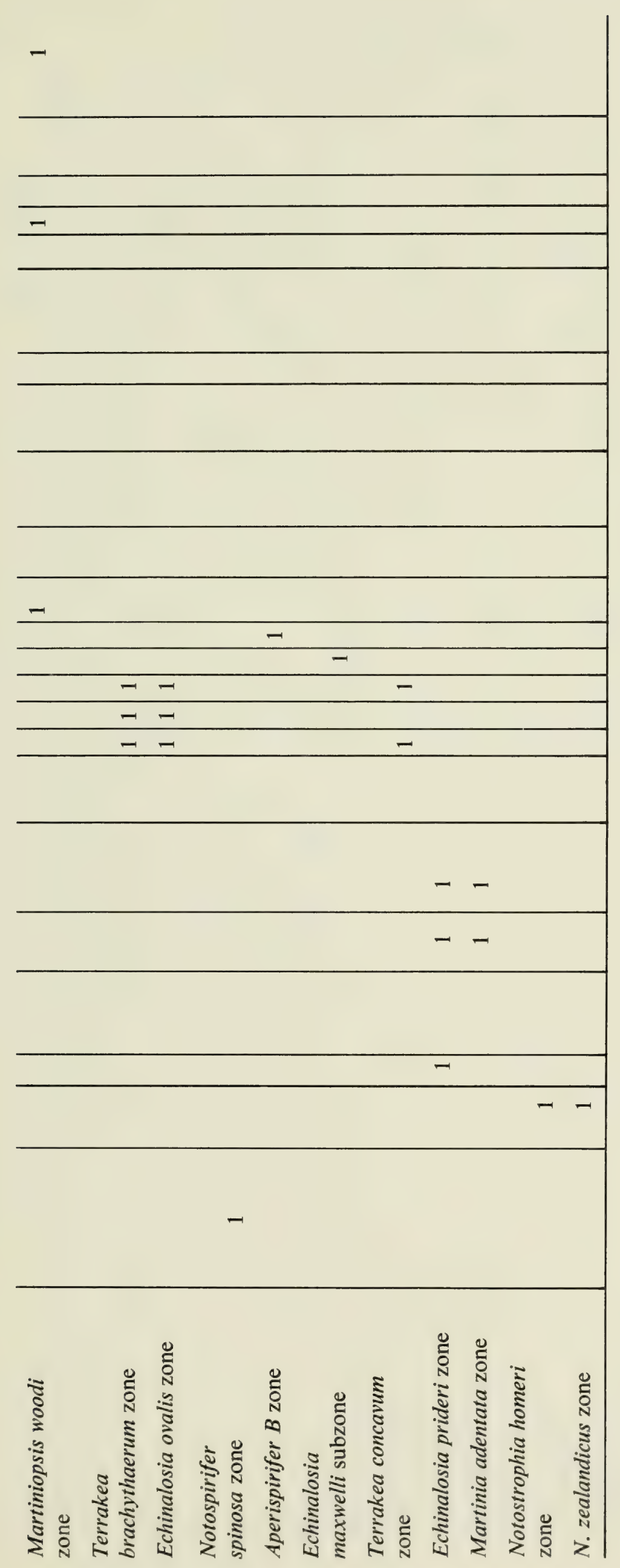


TABLE 4 Distribution of common genera of New Zealand Permian brachiopods in various lithologies.

\begin{tabular}{|c|c|c|c|c|c|c|c|c|c|}
\hline & 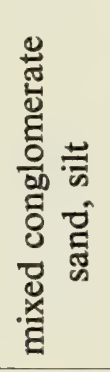 & 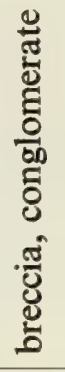 & 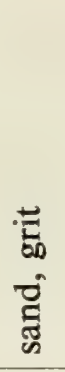 & 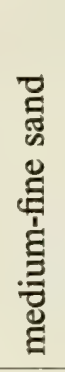 & 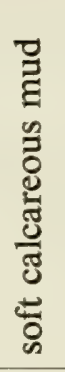 & 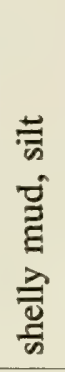 & 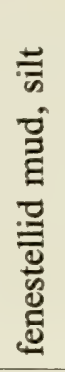 & 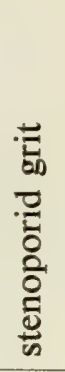 & 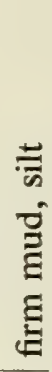 \\
\hline Grumantia, Notostrophia & $x$ & $\times$ & & $\times$ & & & $\times$ & & \\
\hline Capillonia & $x$ & & $x$ & & $x$ & & $\times$ & & $x$ \\
\hline Echinalosia & $x$ & $\times$ & $\times$ & $\times$ & $\times$ & $\times$ & & & \\
\hline Wyndhamia & $\times$ & $\times$ & $\times$ & $\times$ & $\times$ & $\times$ & & & $x$ \\
\hline Cancrinella & $x$ & & & & & & $\times$ & & $x$ \\
\hline Terrakea & $x$ & $\times$ & $\times$ & $x$ & $\times$ & $x$ & $\times$ & & $x$ \\
\hline Plekonella & $x$ & $\times$ & $\times$ & $\times$ & $\times$ & $x$ & $\times$ & & $x$ \\
\hline Attenuatella & $x$ & $x$ & $\times$ & $x$ & $\times$ & & $\times$ & & $x$ \\
\hline Aperispirifer & $x$ & $\times$ & $\times$ & $x$ & $\times$ & $x$ & $\times$ & $\times$ & $x$ \\
\hline Tomiopsis & $x$ & $\times$ & $\times$ & $\times$ & $\times$ & $x$ & $\times$ & & $x$ \\
\hline Notospirifer & & $\times$ & $\times$ & $x$ & & $x$ & $\times$ & & $\times$ \\
\hline Martinia & $x$ & $\times$ & & & & $\times$ & $\times$ & & $x$ \\
\hline Fletcherithyris & & & $\times$ & $x$ & & $x$ & $\times$ & & $x$ \\
\hline Maorielasma & & $x$ & $\times$ & $x$ & & $x$ & $\times$ & & $x$ \\
\hline
\end{tabular}




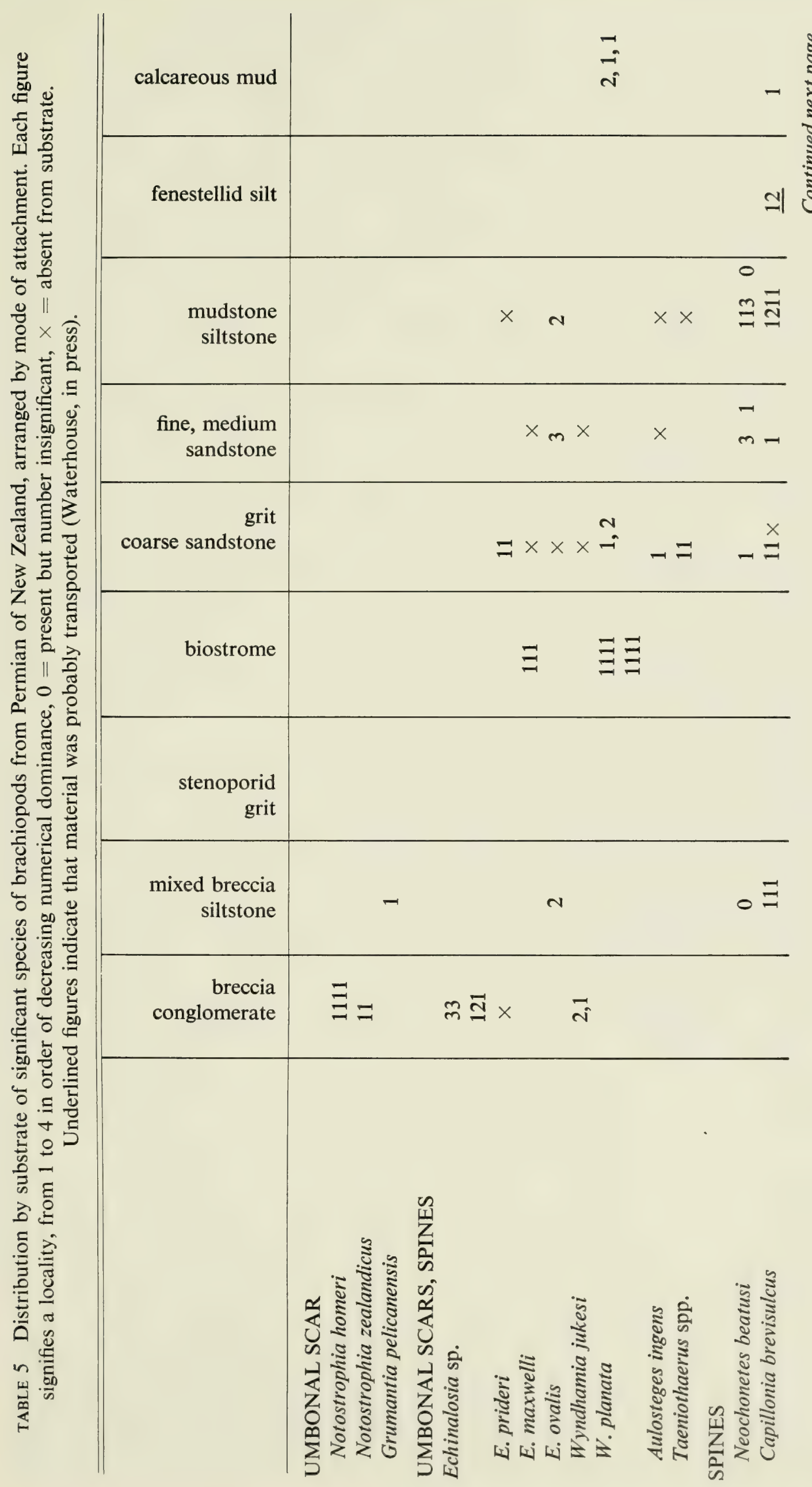




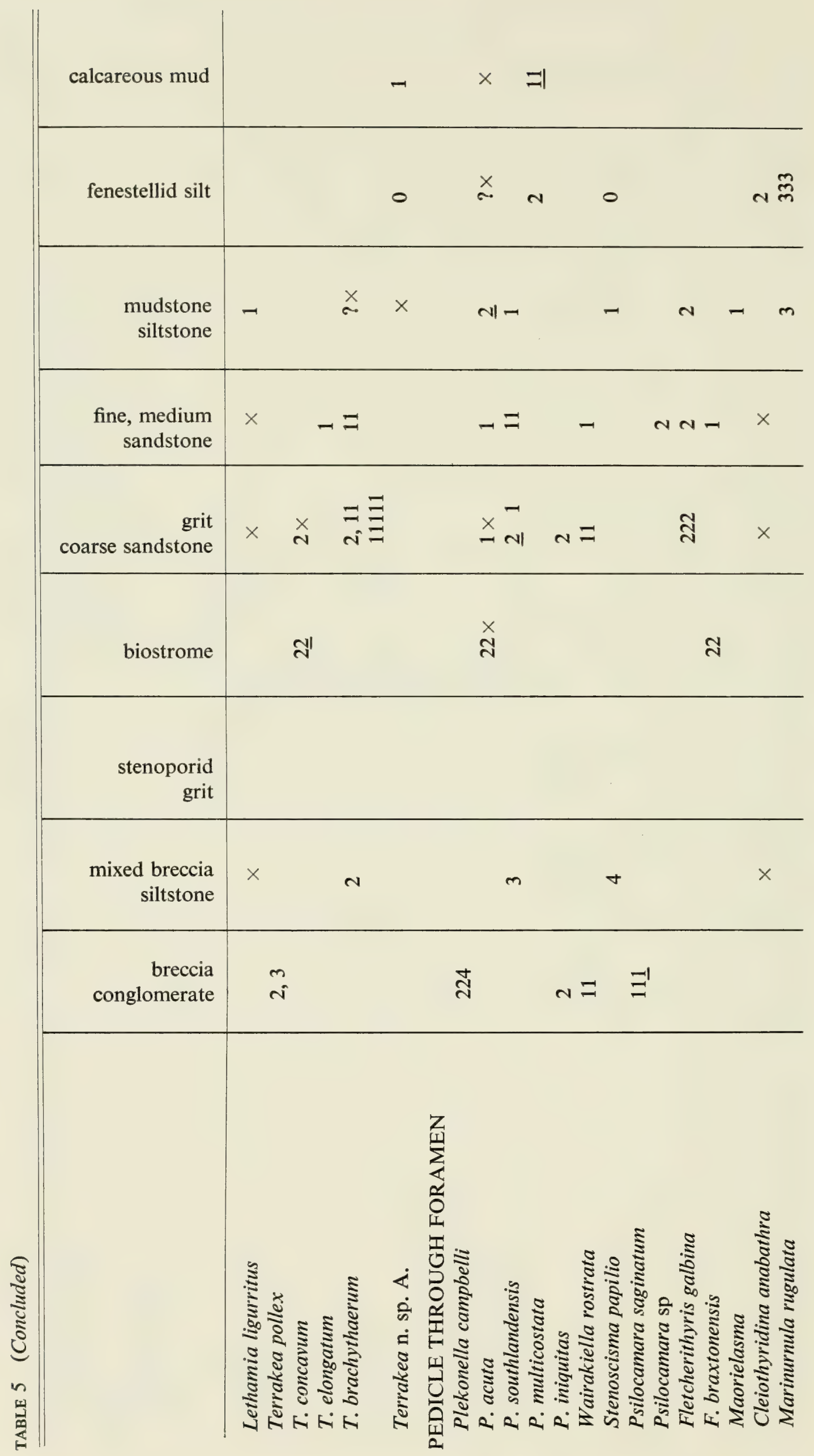



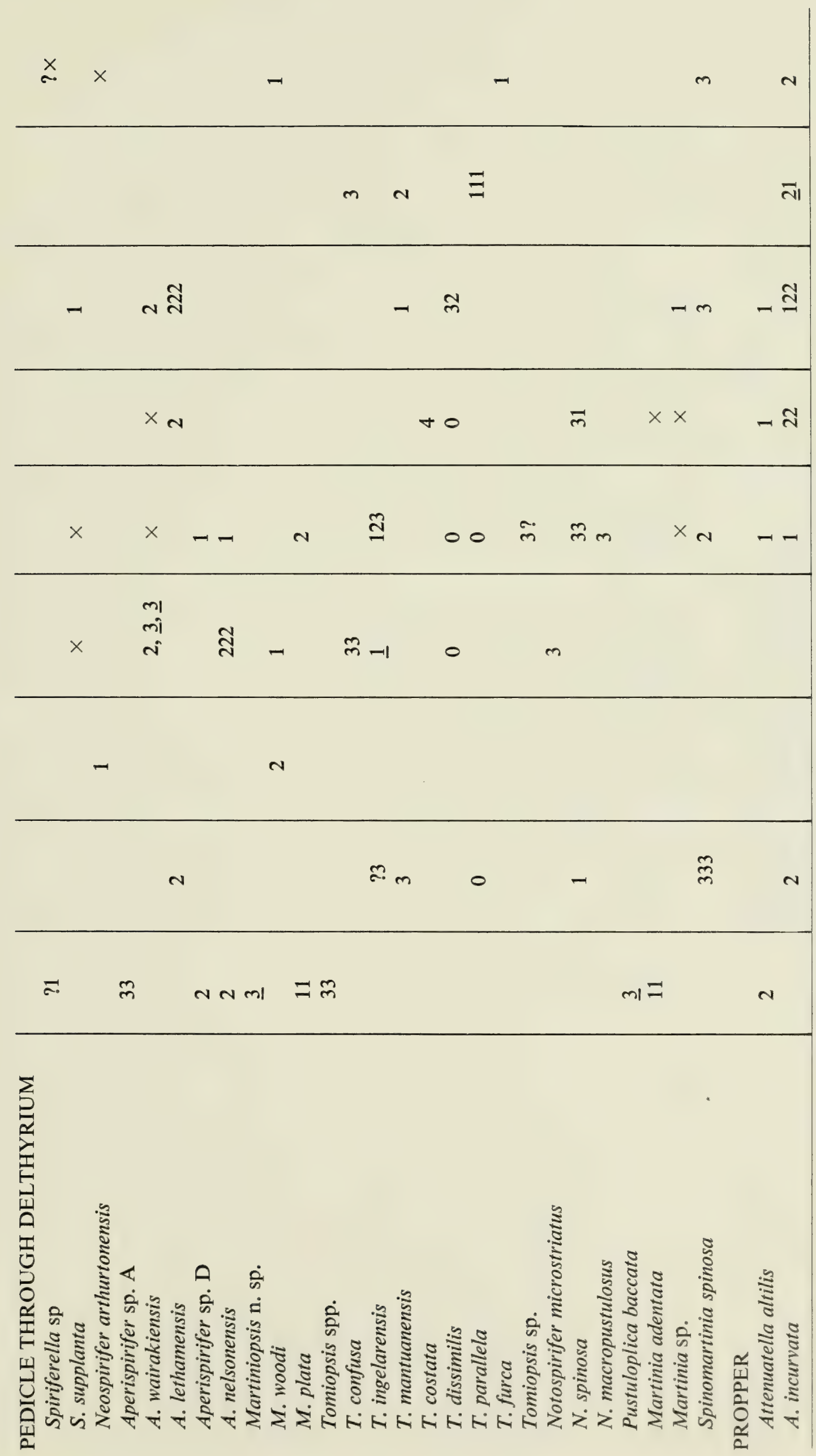


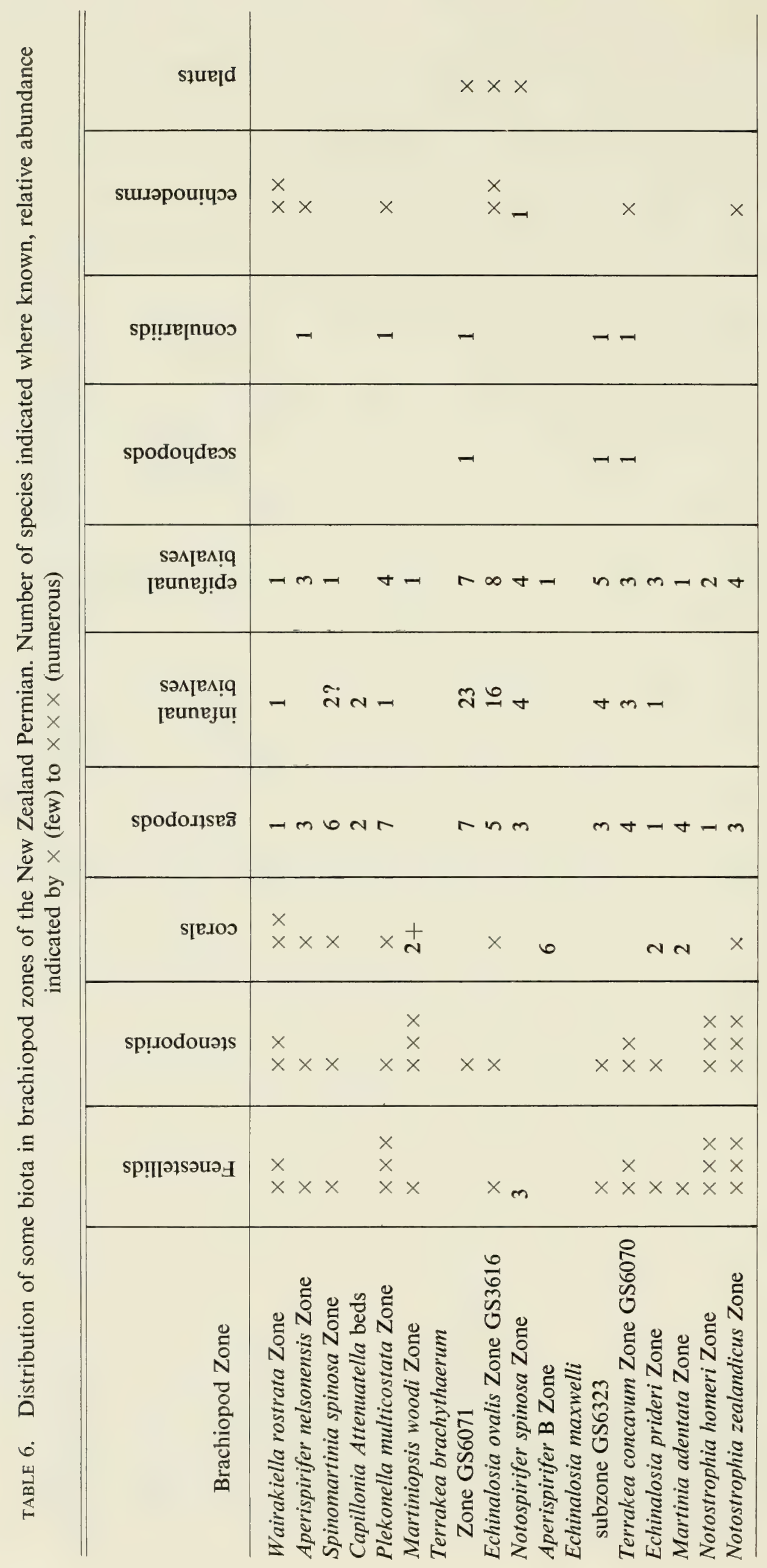


FIGURES 


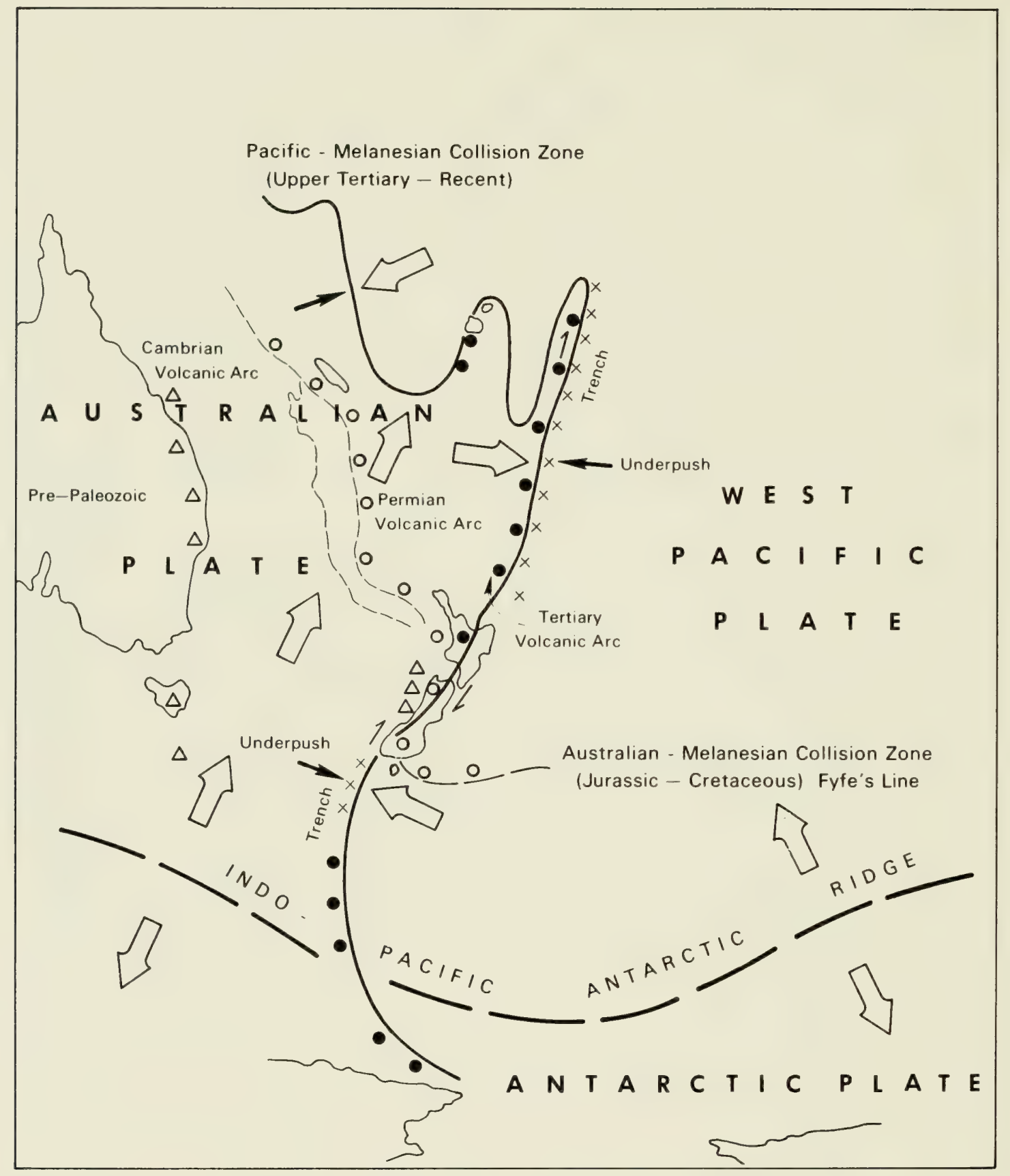

Fig. 1 Relation of New Zealand to past and present leading margins of major tectonic plates, as shown by volcanic arcs indicative of Benioff zones. Particularly relevant is the Permian volcanic arc, consisting of calcalkaline and tholeiitic magmas in a typical lavacline (Waterhouse and Norris, 1972), which was twisted during the Cretaceous orogeny into a spiroform Z-fold at the edge of the Pacific Ocean and subsequently separated 300 miles by transform movement along the Alpine Fault, between the Tonga trench-arc couple in the north, and a less well understood Puysegur ridge, with a possible trench. Permian sequences are best preserved in southern New Zealand, where rocks retain their original east-west orientation. 


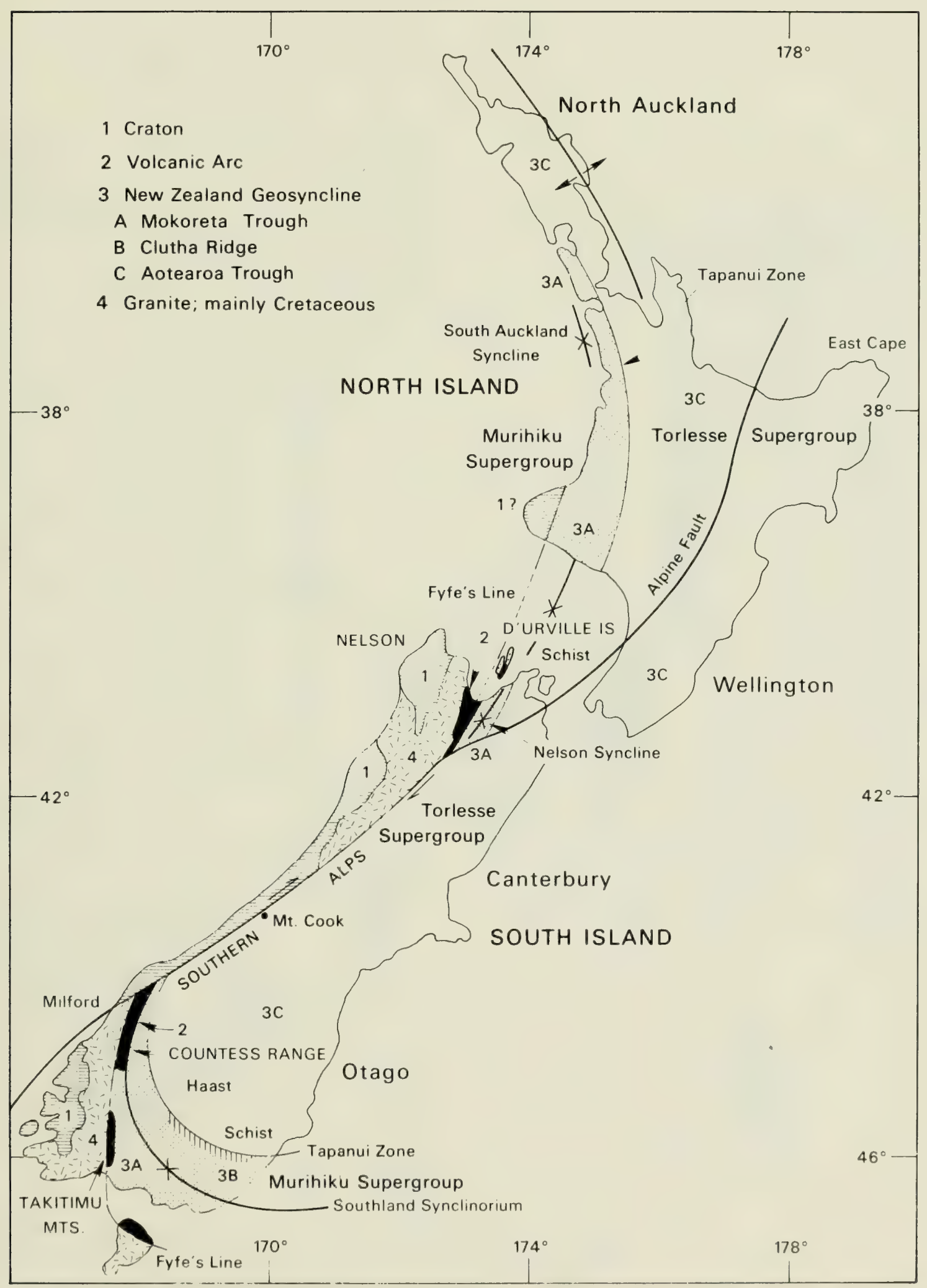

Fig. 2 Distribution of major components of Upper Paleozoic-Mesozoic orogen of New Zealand. The craton, volcanic arc, and geosyncline were present in the Early Permian, and the Mokoreta Trough, Aotearoa Trough, and Clutha Ridge were differentiated in the late Middle Permian. 


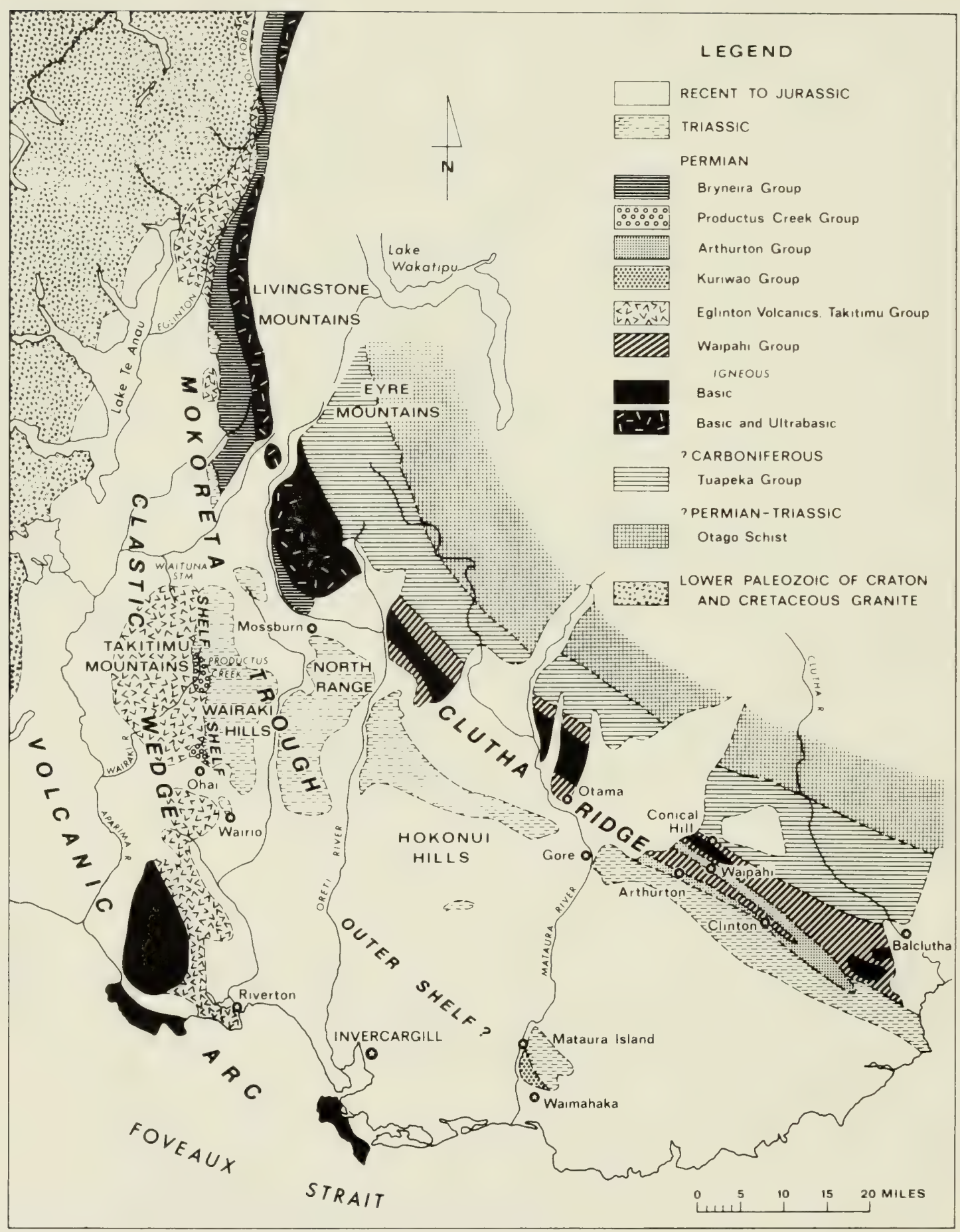

Fig. 3 Geological map of south New Zealand, showing distribution of Permian rocks and formations, with major facies that changed during the period. 


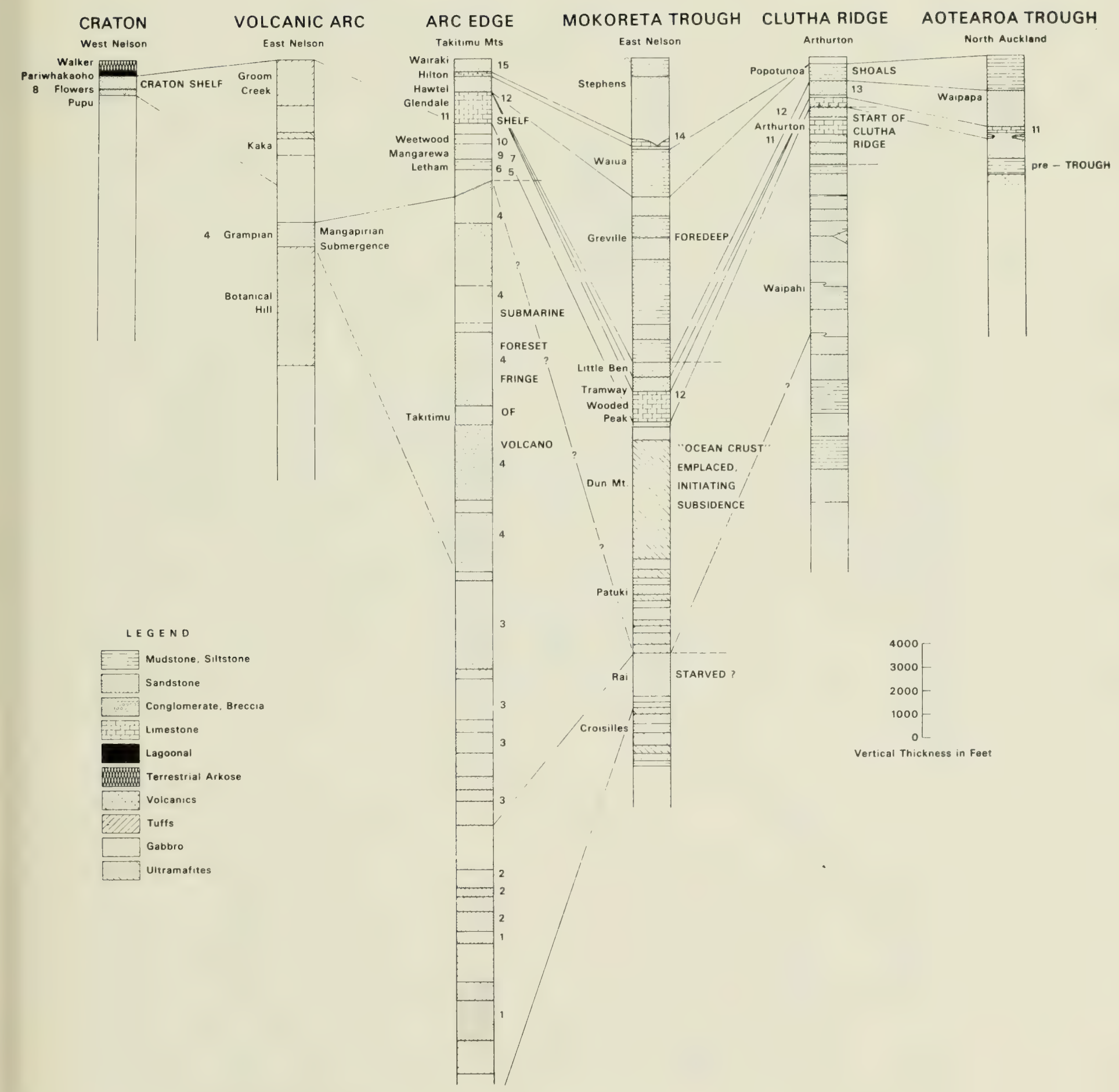

Fig. 4 Lithologic columns for the Permian of New Zealand, from the craton to the outer geosyncline, with brachiopod zones indicated by number (see Table 1). Names of formations given at left, environmental names given at right. 


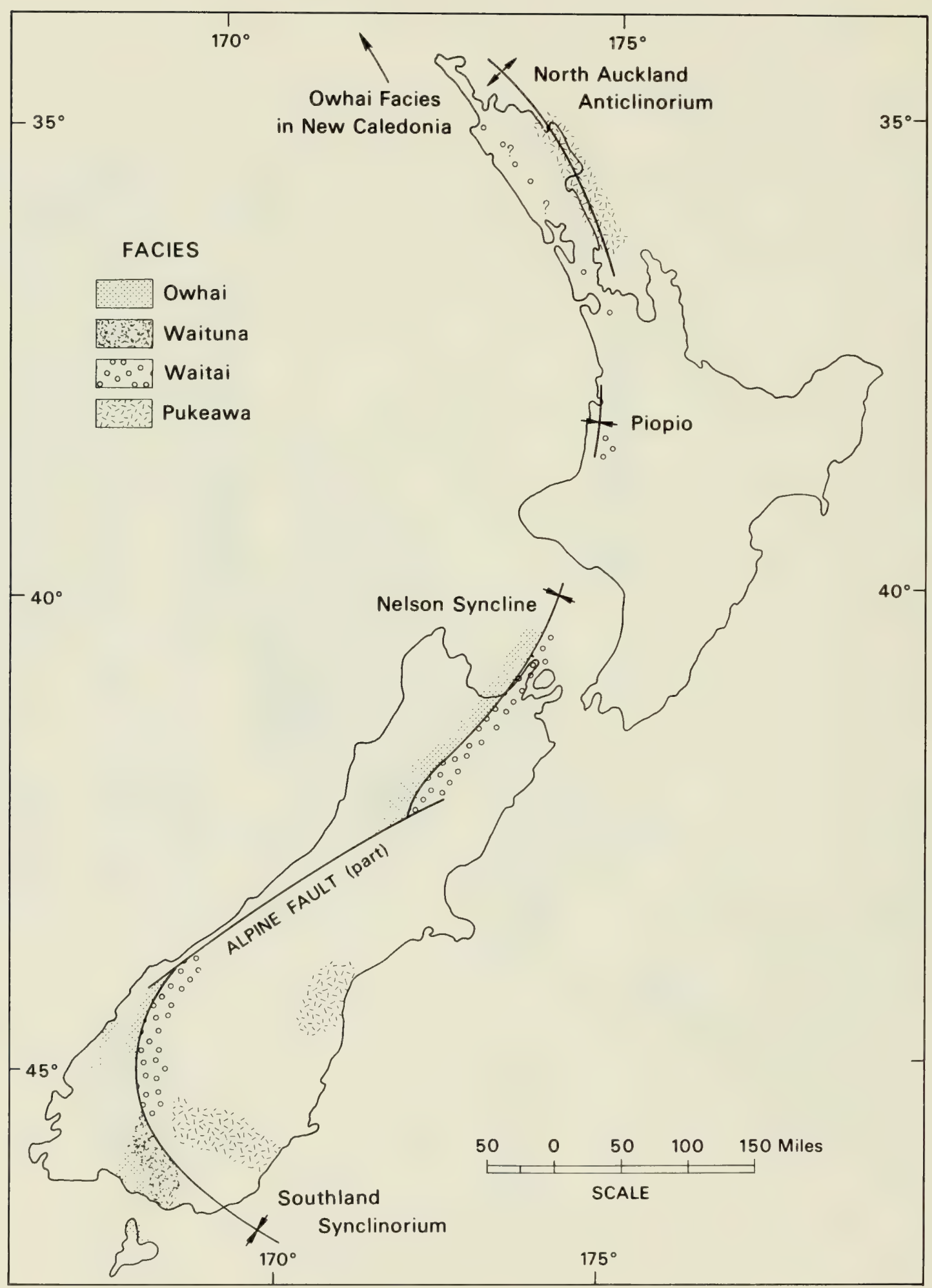

Fig. 5 Distribution of facies during the Early and Middle Permian period in New Zealand. Faulting and folding probably removed the Waituna facies between the Owhai and Waitai facies in the northern part of the Southland Synclinorium and along the Nelson Syncline. 


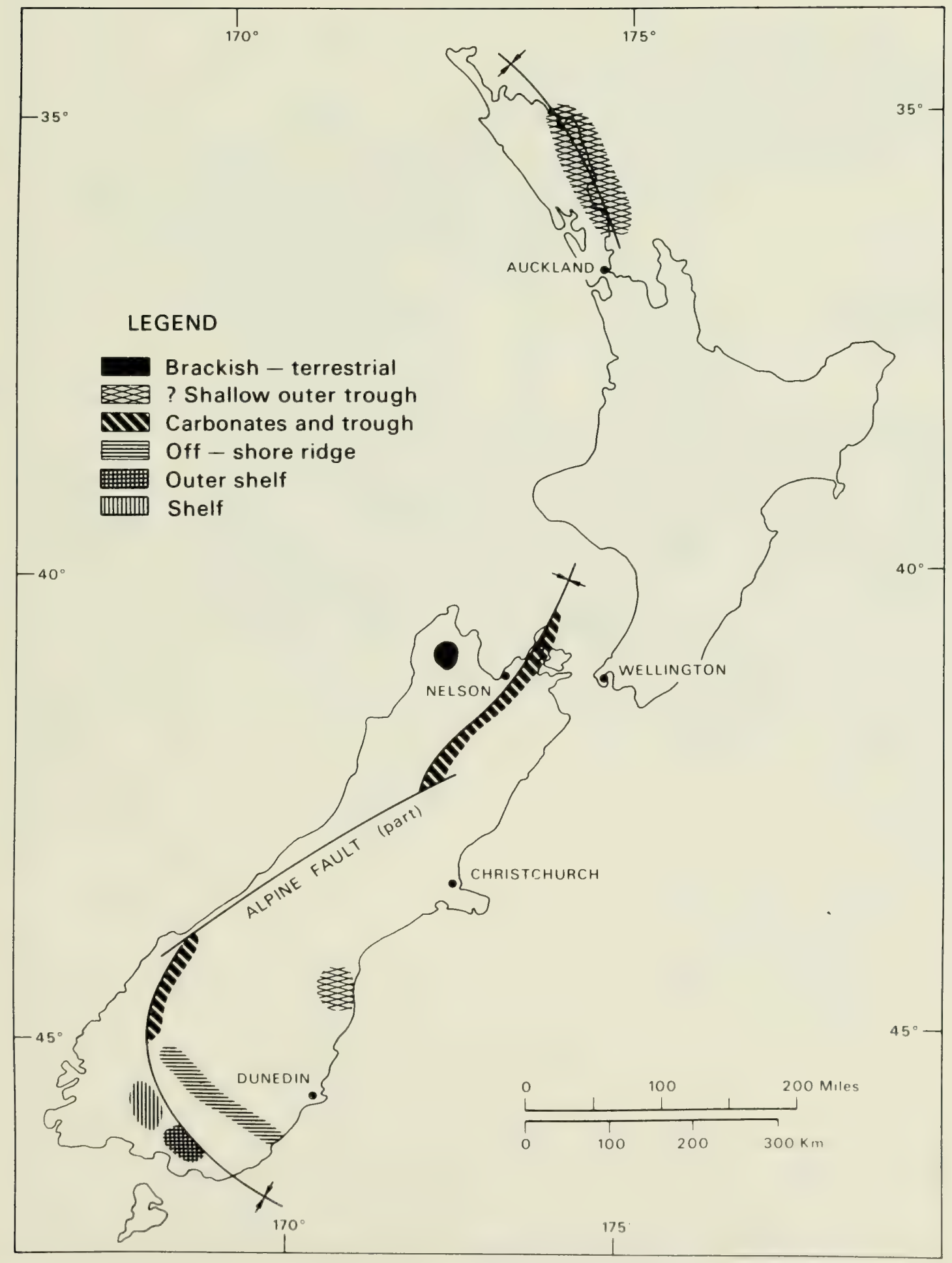

Fig. 6 Distribution of facies in the late Middle Permian period in New Zealand. 


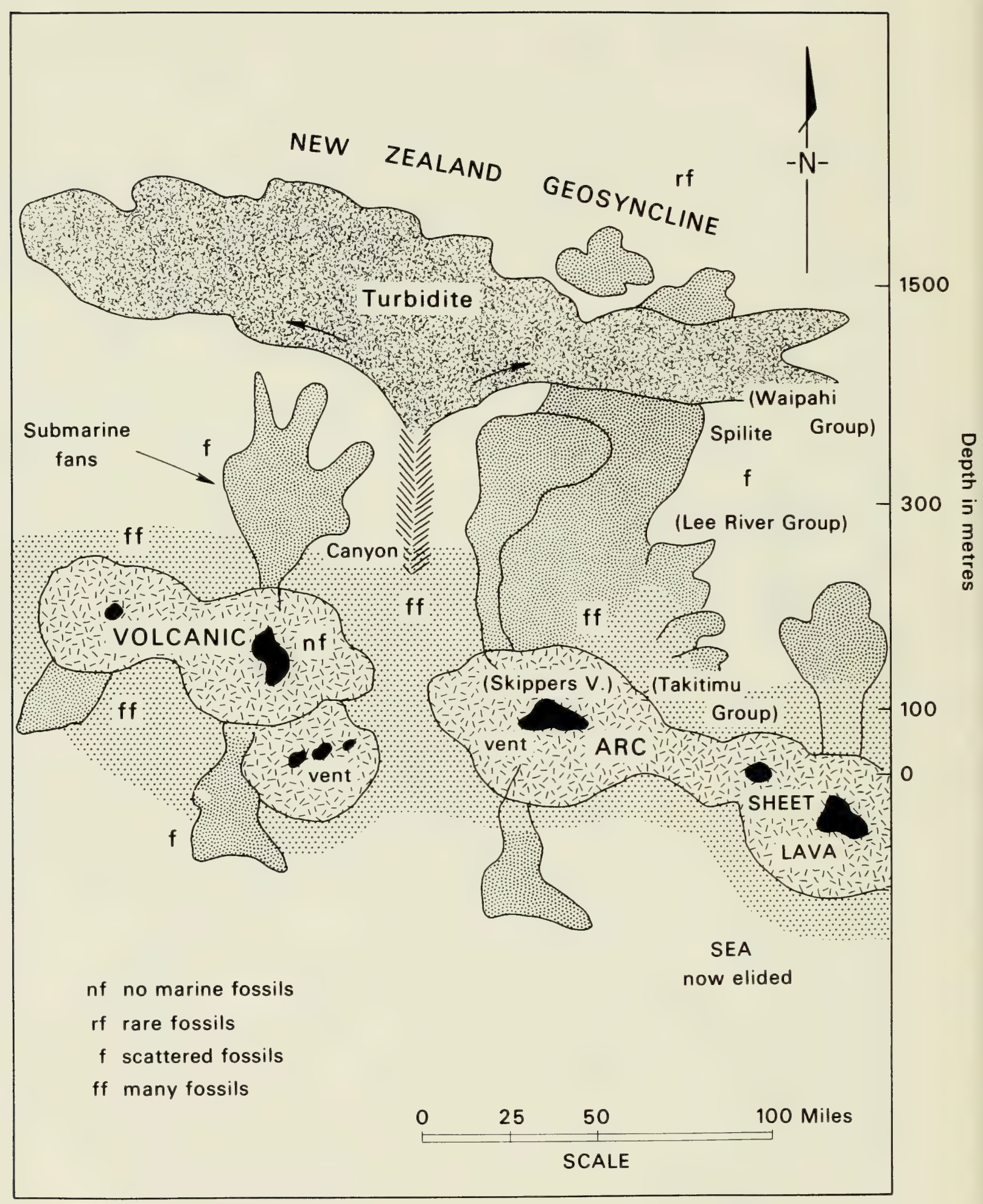

Fig. 7 Paleogeography of the New Zealand geosyncline and volcanic arc during early Permian (e.g., Sakmarian-Baigendzinian Series). Note east-west orientation and southern sea, now elided. Volcanics have one main eruptive line, but may have come from a double arc. Dimensions based largely on a section across Southland syncline north from Stewart Island. 


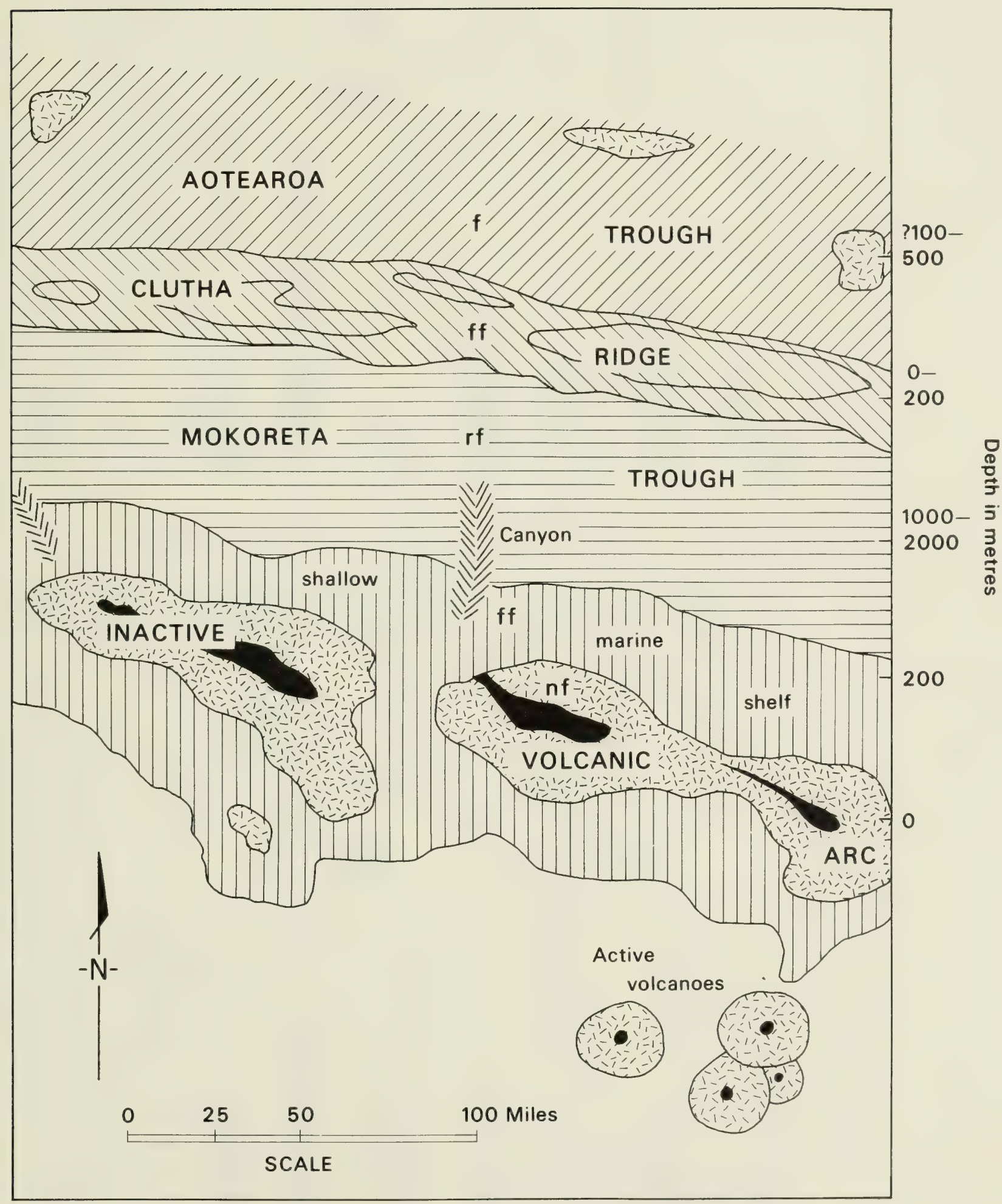

Fig. 8 Paleogeography of the New Zealand geosyncline and volcanic arc during the Tatarian, (Kalabaghian to Baisalian stages) after the elevation of the mid-geosyclinal Clutha Ridge: $n f$ - no marine fossils, $\mathrm{rf}$ - rare marine fossils, $\mathrm{f}$ - scattered marine fossils, and $\mathrm{ff}$ - numerous marine fossils. 


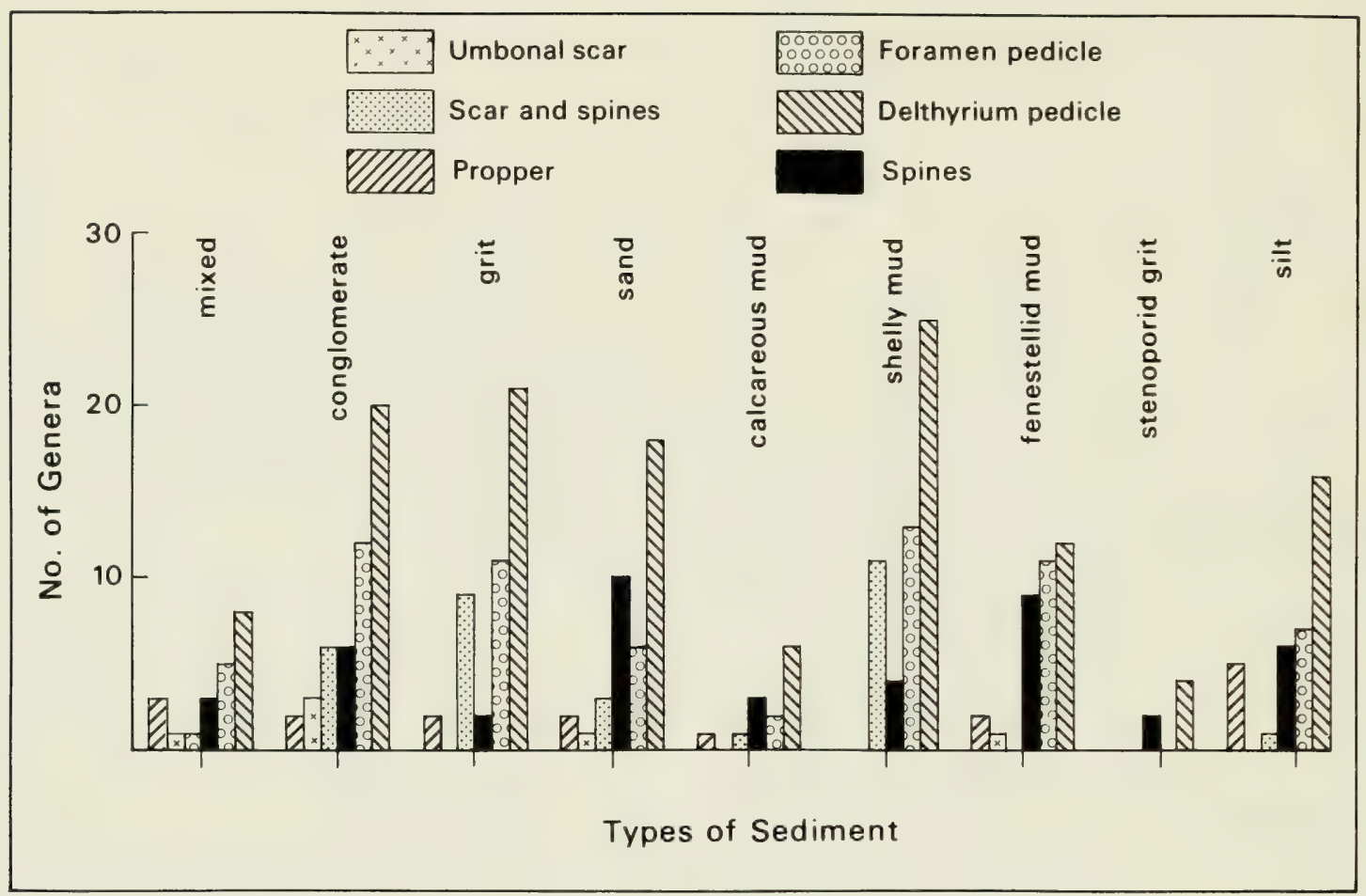

Fig. 9 Percentage distribution of brachiopods in various sediments according to modes of attachment. Each mode of attachment estimated from $100 \%$.

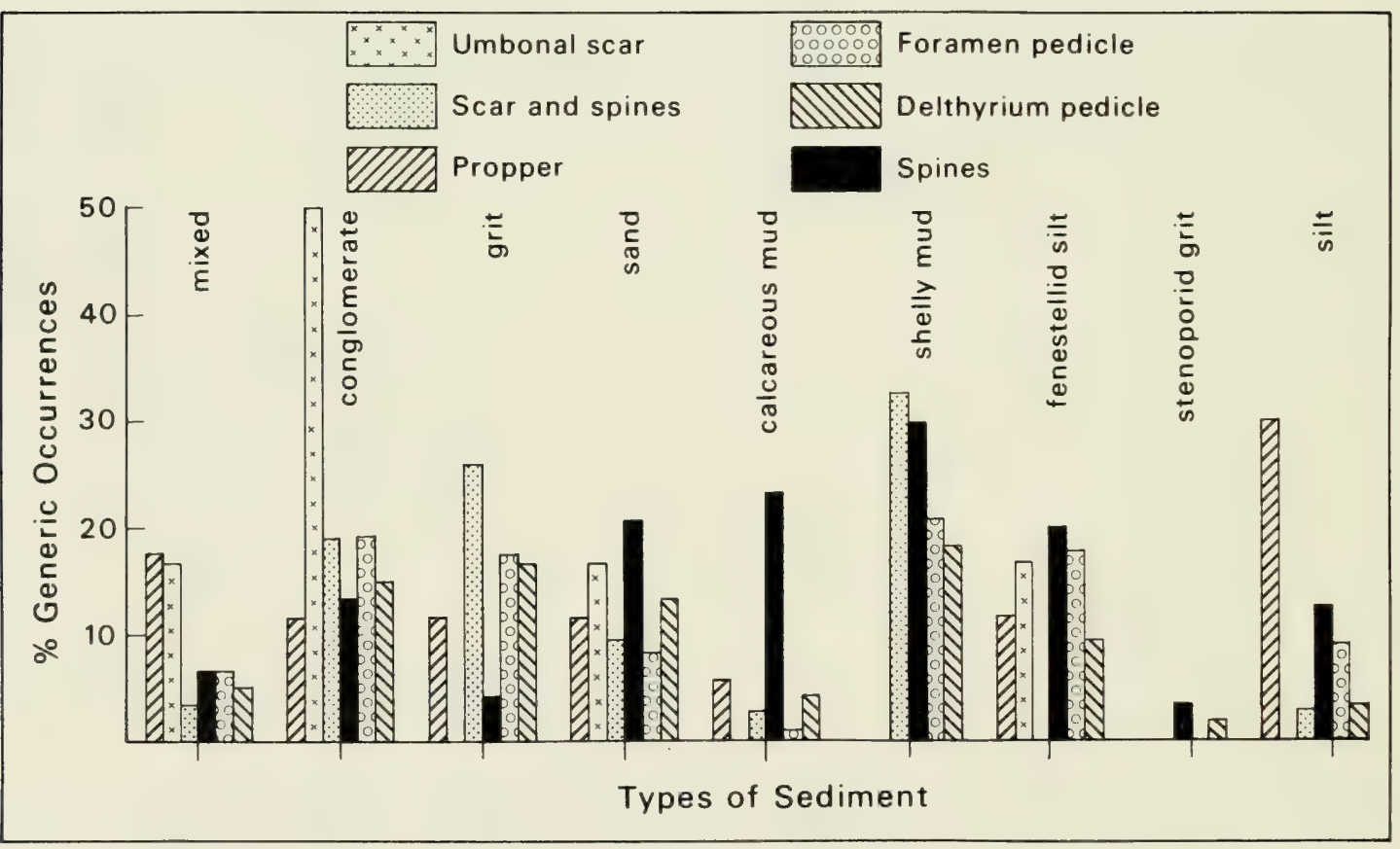

Fig. 10 Distribution of brachiopod genera by number and by mode of attachment in various sediments. 


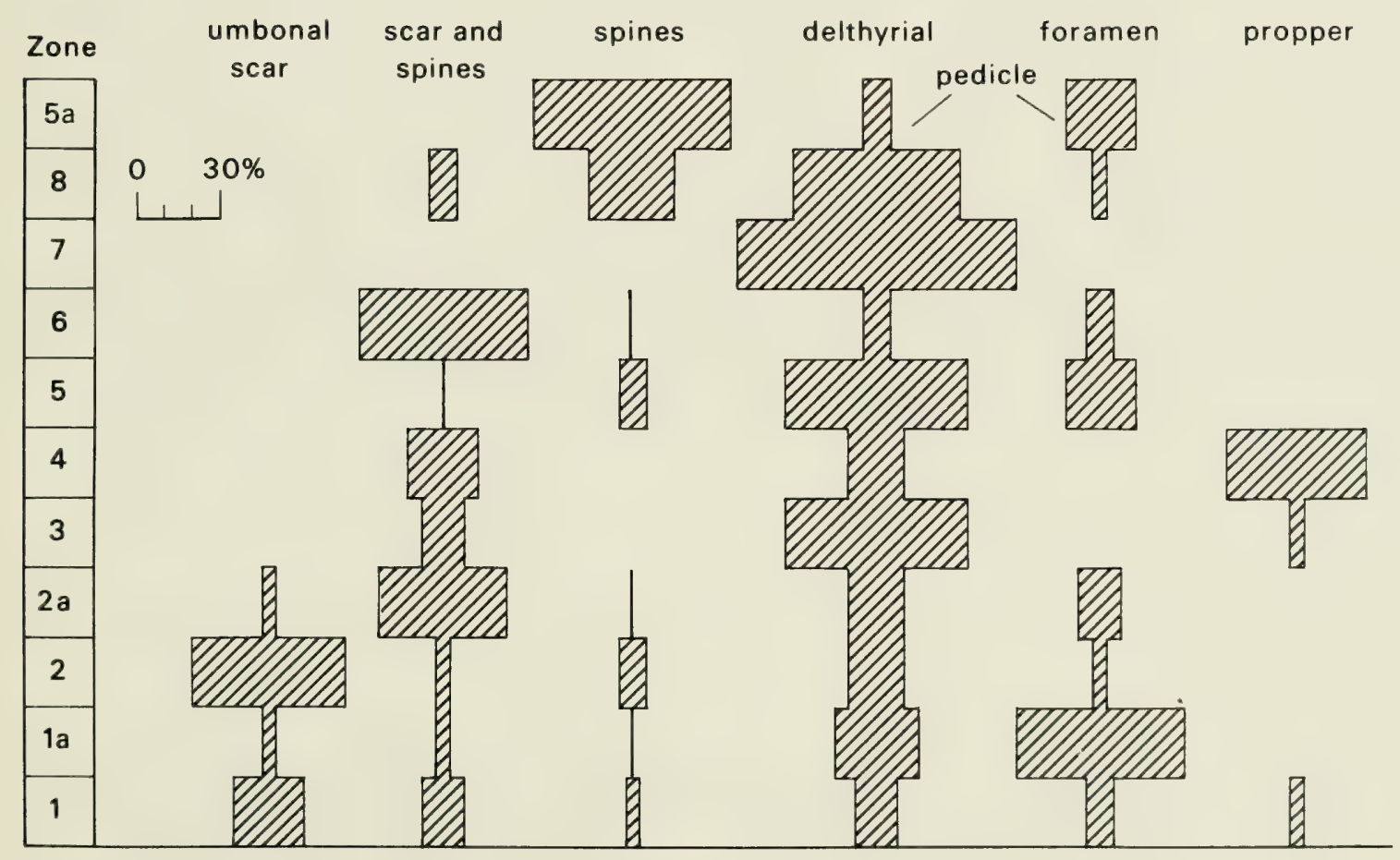

Fig. 11 Distribution of brachiopod individuals, according to attachment mode, in the Early and Middle Permian in New Zealand. Ages of zones are by number (see Table 1). Communities are as follows: 1-Notostrophia zealandicus, 1a-Psilocamara mutchi, 2-Notostrophia homeri, 2aEchinalosia ardua, 3-Martinia adentata, 4-Echinalosia prideri, 5Spiriferella supplanta (based on GS 6070), 6-Echinalosia maxwelli (based on GS 6323), 7-Aperispirifer B, 8-Notospirifer spinosa, 5aNeochonetes beatusi (in upper Terrakea concavum zone) (based on GS 3614). 


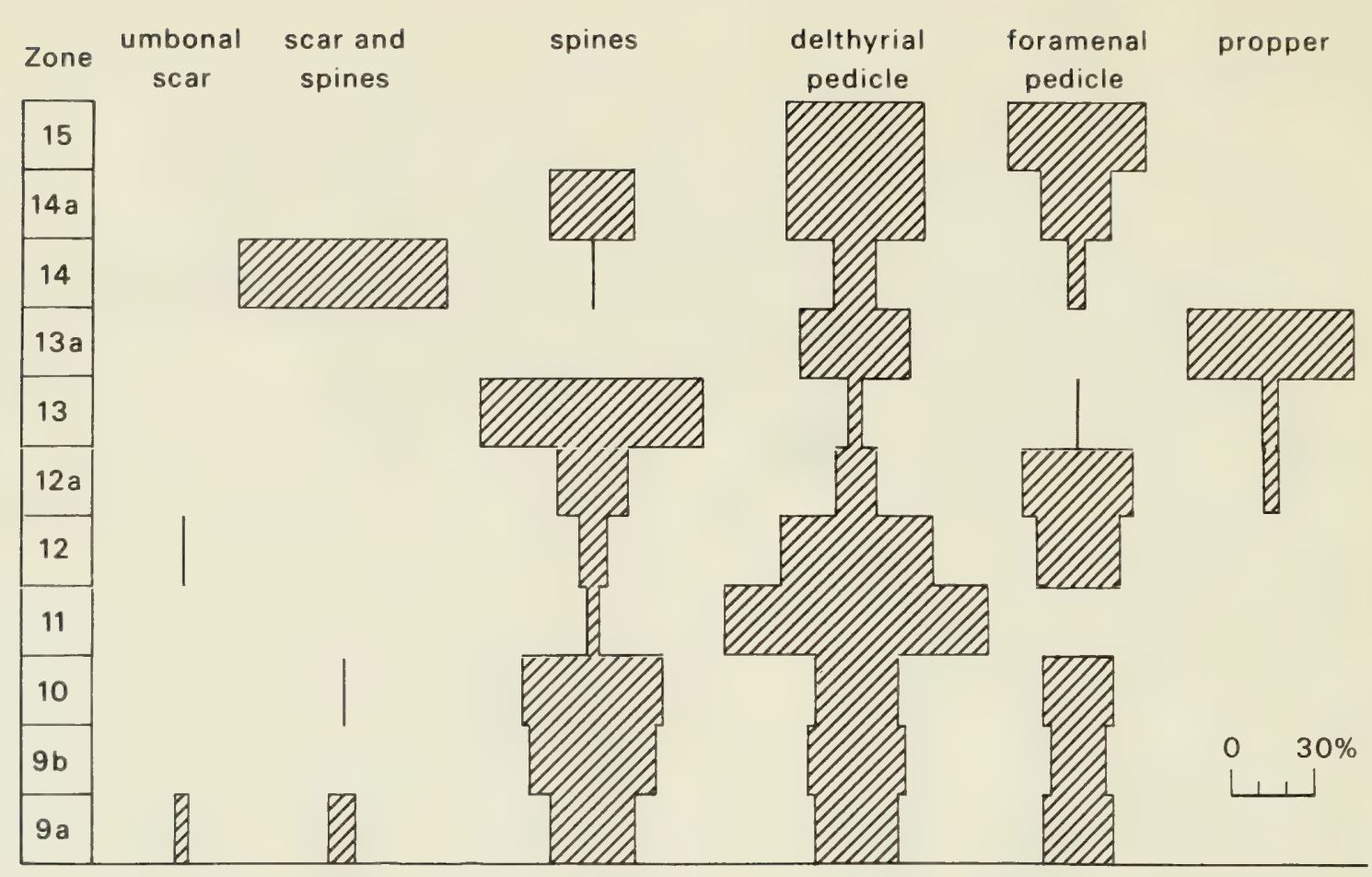

Fig. 12 Distribution of individual brachiopods according to mode of attachment in the Middle and Late Permian of New Zealand. Zones numbered as in Table 1. Communities are as follows: 9a-Terrakea elongatum (based on GS 3616), 9b-Lethamia ligurritus (based on GS 9697), 10-Terrakea brachythaerum (based on GS 6071), 11-Neospirifer arthurtonensis (based on GS 5079), 12-Tomiopsis parallela (based on GS 5077), 12a-Stenoscisma papilio (based on GS 5078), 13-Capillonia brevisulcus (based on GS 1456), 13a-Attenuatella incurvata (based on GS 7803), 14-Wyndhamia planata (based on GS 441), 14a-Aperispirifer nelsonensis (based on GS 7800), 15-Wairakiella rostrata zone. Counts of some communities based on one fossil locality, numbered with prefix GS, with details provided in Waterhouse (1964a, b; 1969c). Others incorporate all counts, specified in Waterhouse (in press).

Fig. 13 Diagrammatic interrelationships between communities of the Aperispirifer fossil biome throughout the Permian in New Zealand, with numbered columns showing a temporal succession of Echinalosia and Wyndhamia generic communities and related correlative communities, numbered according to zone (see Table 1). Supercommunity names are given in underlined capitals. Each oval contains prime species of the community or subcommunity, in order of abundance by species. The two heavy, solid lines (A-A and B-B) represent time intervals occupied by the Attenuatella fossil biome. Below and left of A-A are given the Aktastinian communities, between A-A and B-B are the early Middle Permian communities of Kungurian to Kazanian age, and at the top are the Late Permian communities of Vedian age. 


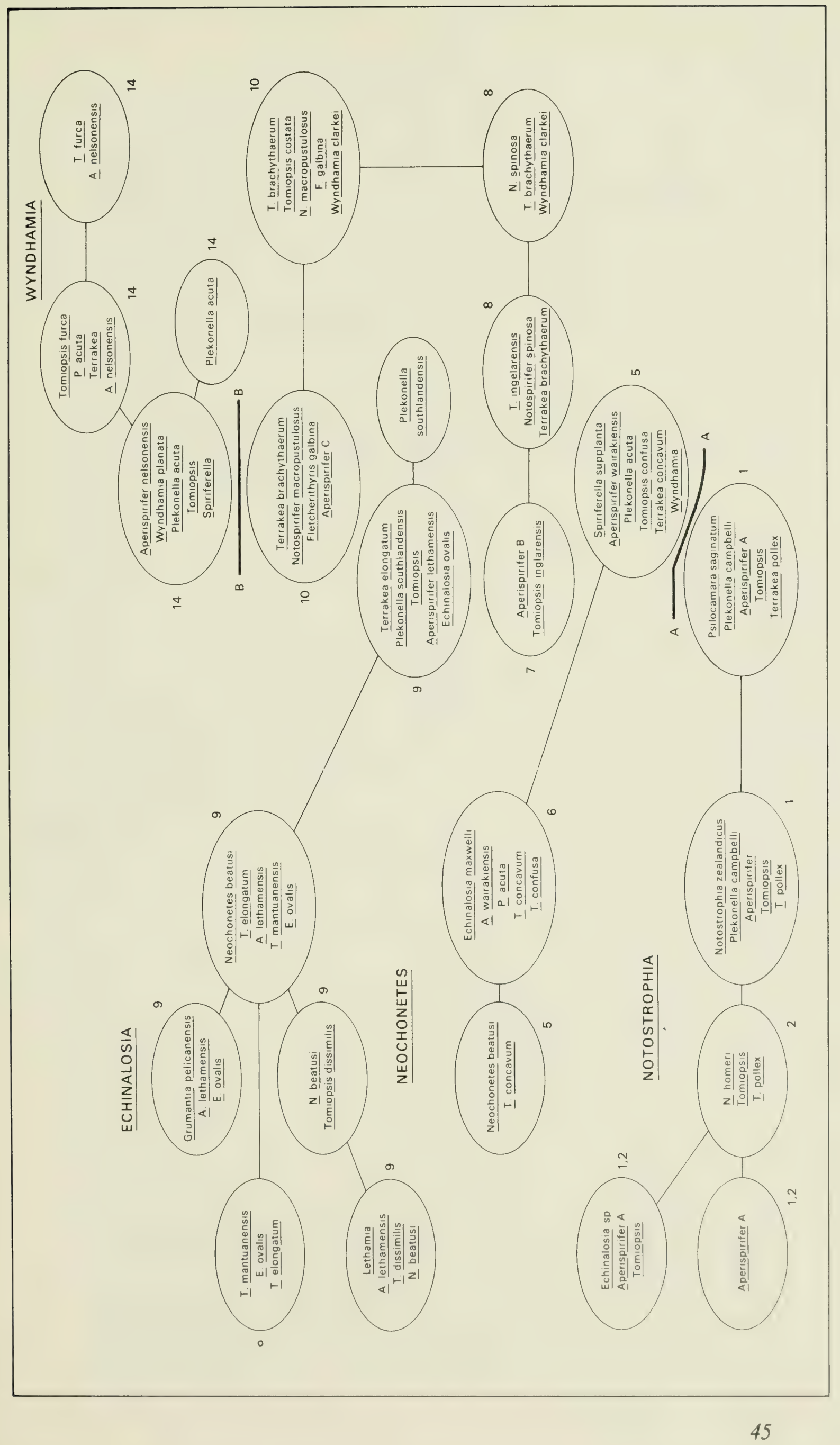




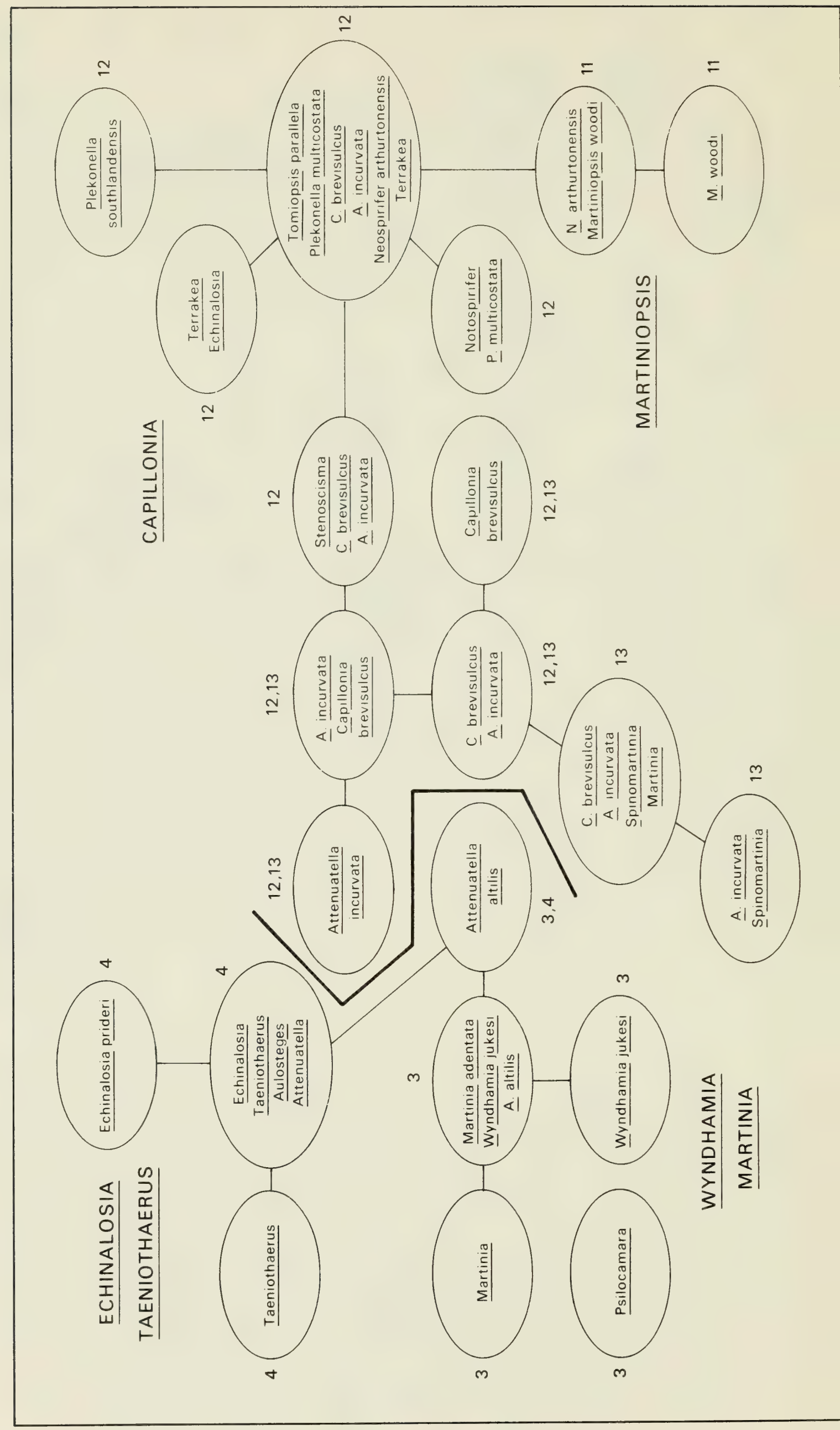




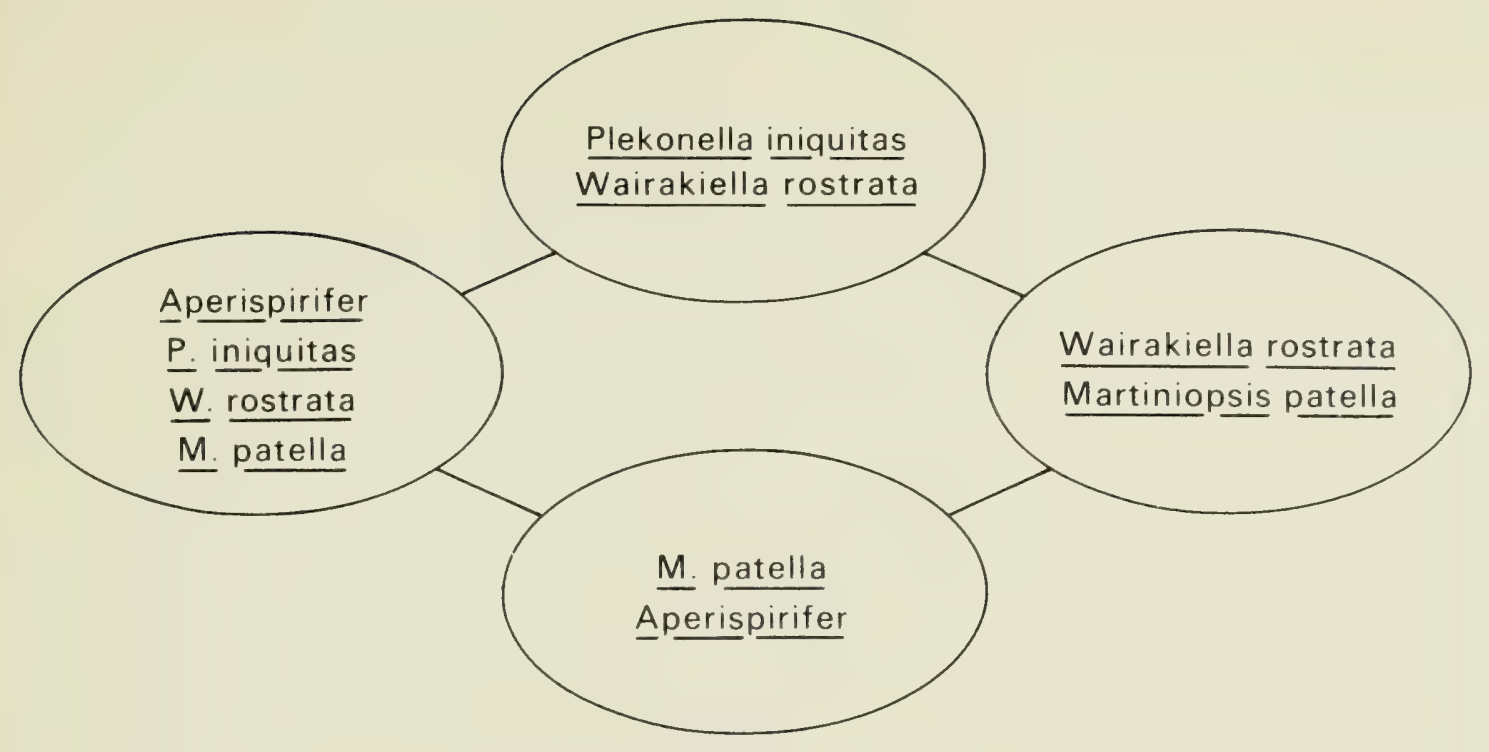

Fig. 15 Diagrammatic representation of brachiopod communities of the shortlived Wairakiella rostrata zone in the late Permian of New Zealand. All communities integrade.

Fig. 14 Diagrammatic relationship of communities and subcommunities of the Attenuatella biome in the Permian of New Zealand in two main age groups as related to Attenuatella altilis (Baigendzinian Series) to the left and $A$. incurvata (Kalabaghian and Chhidraan Stages) to the right. Supercommunities are shown in underlined capitals. Communities are numbered according to the zone in which they were found (see Table 1). 


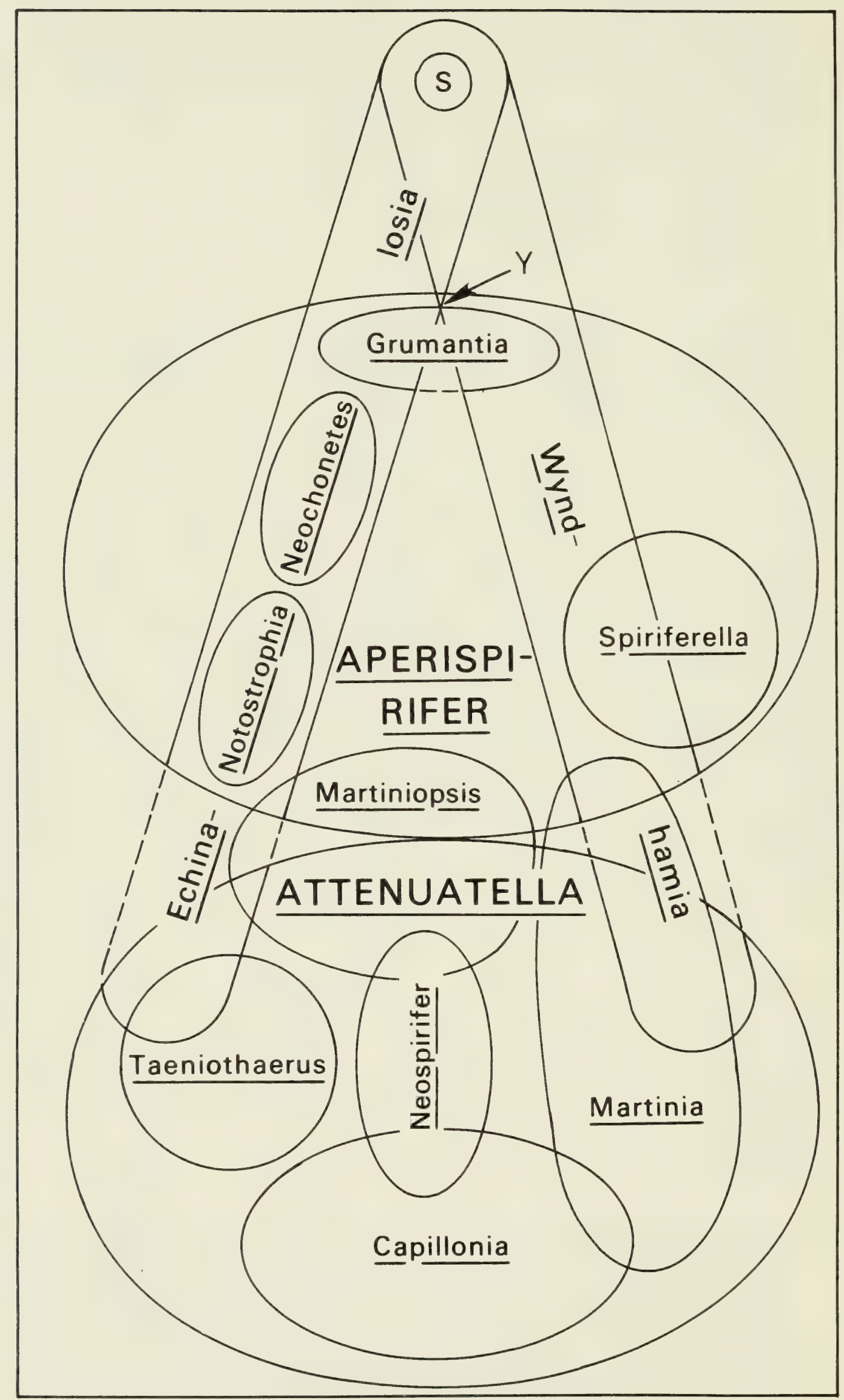


Fig. 16 Diagrammatic representation of interrelationships of the most important brachiopod genera that formed generic communities and supercommunities in the New Zealand Permian, showing degree to which genera coexisted or were mutually exclusive. Most genera existed within the range of either Aperispirifer or Attenuatella, but Wyndhamia and Echinalosia coexisted in a cold climate at a high latitude (Waterhouse and Bonham-Carter, 1972; Waterhouse, 1969a) below the temperature tolerance of Aperispirifer. Distribution is diagrammatic, but demonstrates the interrelated distributions of taxa except Wyndhamia and Echinalosia where lines are dashed (the crossed lines where the two could have occurred together at y should lie beyond Aperispirifer in New Zealand, but the three coexist in parts of east Australia): S Sulciplica. 




ISBN 0-88854-138-4 